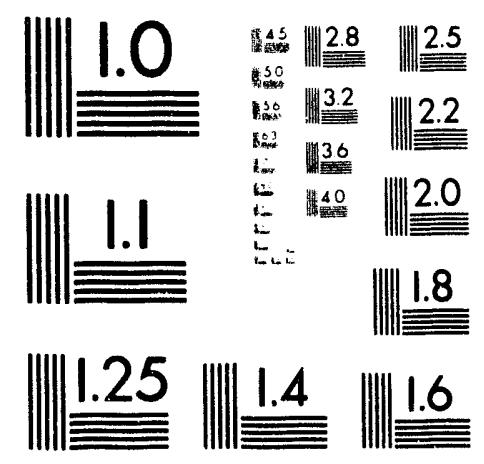



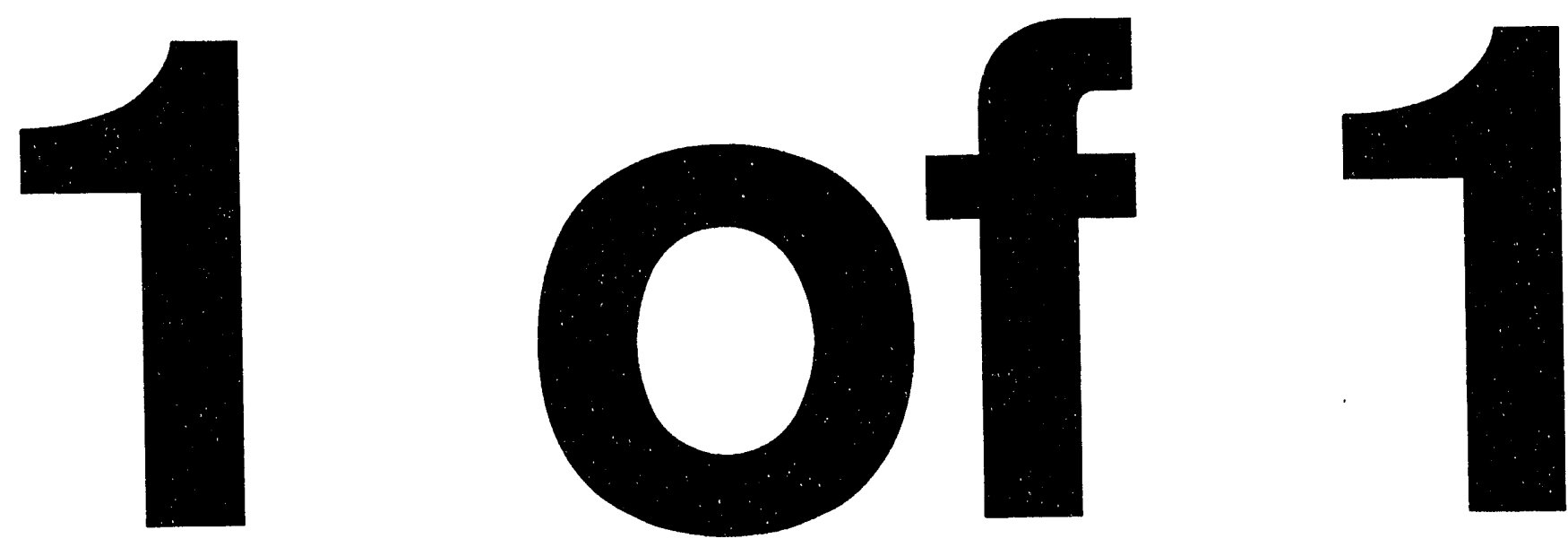
SAND92 - 7291

Unlimited Release

UC -721

\section{Creep Tests on Clean and Argillaceous Salt From the Waste Isolation Pilot Plant}

K. D. Mellegard, T. W. Pfeifle

$\mathrm{RE} / \mathrm{SPEC}$ Inc.

P. O. Box 725

Rapid City, SD 57709

Prepared by Sandia National Laboratories Albuquerque, New Mexico 87185 and Livermore, California 94550 for the United States Department of Energy under Contract DE-AC04-76DP00789

Printed May 1993 
Issued by Sandia National Laboratories, operated for the United States Department of Energy by Sandia Corporation.

NOTICE: This report was prepared as an account of work sponsored by an agency of the United States Government. Neither the United States Government nor any agency thereof, nor any of their employees, nor any of their contractors, subcontractors, or their employees, makes any warranty, express or implied, or assumes any legal liability or responsibility for the accuracy, completeness, or usefulness of any information, apparatus, product, or process disclosed, or represents that its use would not infringe privately owned rights. Reference herein to any specific commercial product, process, or service by trade name, trademark, manufacturer, or otherwise, does not necessarily constitute or imply its endorsement, recommendation, or favoring by the United States Government, any agency thereof or any of their contractors or subcontractors. The views and opinions expressed herein do not necessarily state or reflect those of the United States Goverument, any agency thereof or any of their contractors.

Printed in the United States of America. This report has been reproduced directly from the best available copy.

Available to DOE and DOE contractors from

Office of Scientific and Technical Information

PO Box 62

Oak Ridge, TN 37831

Prices available from (615) 576-8401, FTS 626-8401

Available to the public from

National Technical Information Service

US Department of Commerce

5285 Port Royal Rd

Springfield, VA 22161

NTIS price codes

Printed copy: A04

Microfiche copy: A01 
SAND92-7291

Distribution

Unlimited Release

Printed May 1993

Category UC-721

\title{
Creep Tests on Clean and Argillaceous Salt From the Waste Isolation Pilot Plant
}

\author{
K.D. Mellegard \\ T.W. Pfeifle \\ RE/SPEC Inc. \\ P. O. Box 725 \\ Rapid City, SD 57709
}

\begin{abstract}
Fifteen triaxial compression creep tests were performed on clean and argillaceous salt from the Waste Isolation Pilot Plant (WIPP). The temperatures in the tests were either $25^{\circ} \mathrm{C}$ or $100^{\circ} \mathrm{C}$ while the stress difference ranged from $3.5 \mathrm{MPa}$ to $21.0 \mathrm{MPa}$. In all tests, the confining pressure was $15 \mathrm{MPa}$. Test duration ranged from 23 to 613 days with an average duration of 300 days.

The results of the creep tests supplemented earlier testing and were used to estimate two parameters in the Modified Munson-Dawson constitutive law for the creep behavior of salt. The two parameters determined from each test were the steady-state strain rate and the transient strain limit. These estimates were combined with parameter estimates determined from previous testing to study the dependence of both transient and steady-state creep deformation on stress difference. The exponents on stress difference determined in this study were found to be consistent with revised estimates of the exponents reported by other investigators.
\end{abstract}

\footnotetext{
- This report was prepared by RE/SPEC Inc. under Contract No. 05-7502 with Sandia National Laboratories.
} 


\section{CONTENTS}

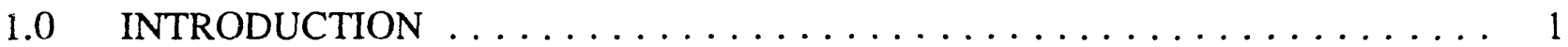

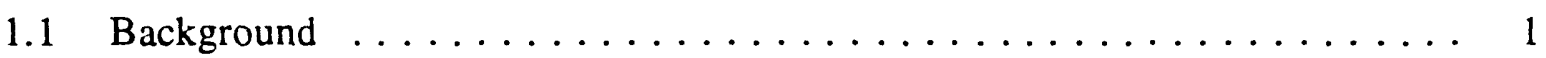

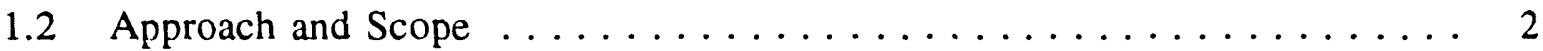

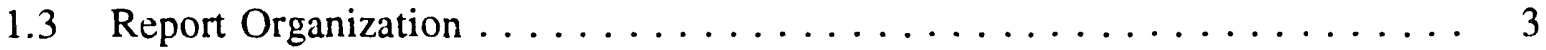

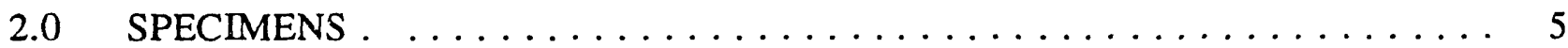

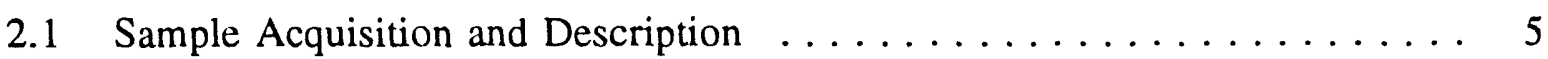

2.2 Specimen Preparation . . . . . . . . . . . . . . . . . 5

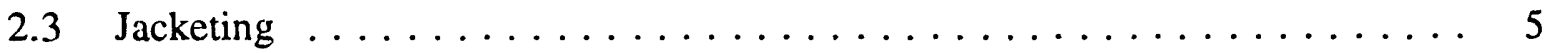

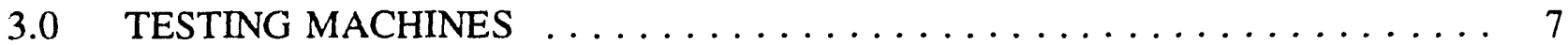

3.1 Load Frames $\ldots \ldots \ldots \ldots \ldots \ldots \ldots \ldots \ldots \ldots \ldots \ldots \ldots \ldots \ldots$

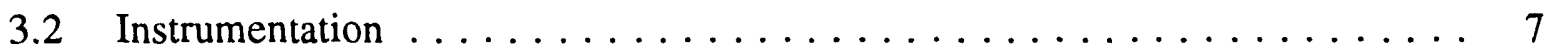

3.3 Calibration .......................... 9

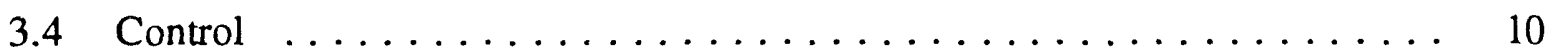

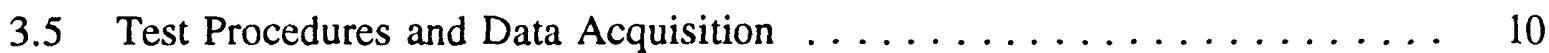

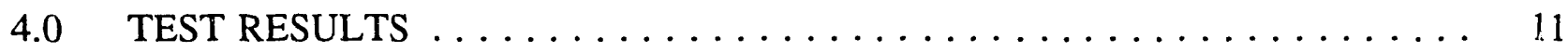

4.1 Strain-Versus-Time Curves . . . . . . . . . . . . . . . . . 11

4.1 .1 Clean Salt $\ldots \ldots \ldots \ldots \ldots \ldots \ldots \ldots \ldots \ldots \ldots \ldots \ldots$

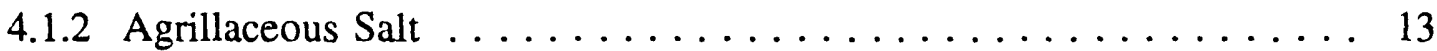

4.2 Fitting Parameters $\ldots \ldots \ldots \ldots \ldots \ldots \ldots \ldots \ldots \ldots \ldots \ldots$

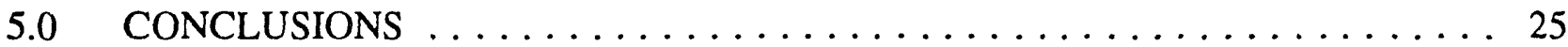

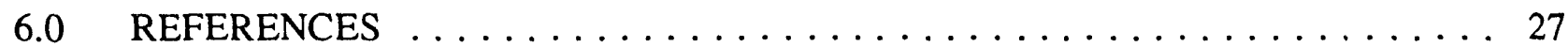




\section{FIGURES}

3-1. Test machine load frame. . . . . . . . . . . . . . . . . 8

4-1. Typical strain-versus-time curves for WIPP salt. . . . . . . . . . . . . 12

4-2. $\log _{10}$ steady-state strain rate as a function of $\log _{10}$ normalized stress for clean salt. 18

4-3. $\log _{10}$ steady-state strain rate as a function of $\log _{10}$ normalized stress for argillaceous salt. . . . . . . . . . . . . . . . . . . 19

4-4. $\log _{10}$ transient strain limit as a function of $\log _{10}$ stress for clean salt. . . . . . . 22

4-5. $\log _{10}$ transient strain limit as a function of $\log _{10}$ stress for argillaceous salt. . . . . 23

\section{TABLES}

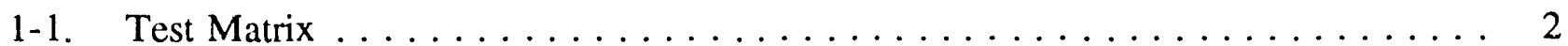

4-1. Steady-State Strain Rates and Transient Strain Limits

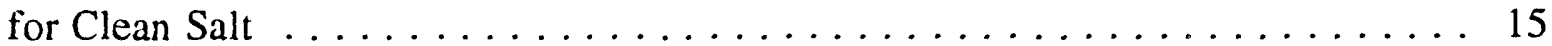

4-2. Steady-State Strain Rates and Transient Strain Limits for Argillaceous Salt . . . . . . . . . . . . . . . . . . 17

4-3. Summary of Stress Exponent Determinations for WIPP Salt . . . . . . . . . 21 


\subsection{INTRODUCTION}

\subsection{Background}

The Waste Isolation Pilot Plant (WIPP) is a research facility sited in a bedded salt formation in southeastern New Mexico. It is located in the Delaware Basin, approximately 660 $\mathrm{m}$ below the surface in the Salado Formation. The purpose of WIPP is to demonstrate the technology for safe handling and disposal of radioactive wastes produced by defense activities. Advanced technologies are being developed to supplement existing practices in support of the performance assessment calculations and activities necessary to demonstrate compliance to a number of regulatory requirements.

Salt has been identified as a good geologic material to host a nuclear waste repository because of several favorable characteristics. Salt has a high ductility that will alleviate fracturing and will aid in encapsulating the waste over the long repository storage times. The creep behavior of the salt must be characterized accurately so that a repository can be designed and constructed to operate safely during the preclosure phase and to assure the adequate containment of the waste during the postclosure phase.

The creep of salt is characterized by constitutive equations that relate the strain rate to the stress, temperature, and history of deformation. One set of constitutive equations that has been proposed to model the deformation of WIPP salt is the Munson-Dawson (M-D) model which is based on the micromechanisms that are thought to control the deformation at steady state under the stresses and temperatures expected for a nuclear waste repository (Munson and Dawson, 1979, 1982a, 1982b, 1984; Munson, 1979; Munson et al., 1989). Some of the parameters in the M-D model are evaluated by analyzing strain-versus-time data from triaxial compression creep tests performed at stresses and temperatures in the ranges expected in a nuclear waste repository.

A substantial number of earlier tests have been performed on specimens from drillholes near the WIPP and from the WIPP workings. These data have been reported and used to evaluate the inelastic parameters in the M-D model. The earlier existing data have been separated into two material types; clean salt and argillaceous salt with separate parameter values being reported for both types of materials. When these early data were examined to determine distribution functions for the creep parameters, significant gaps were found in an already sparce database. It was apparent that supplenental tests would be necessary to increase the database in some areas of the distribution. The purpose of the work described in this report is to 
supplement these existing data with data from additional tests performed on salt from the workings at the WIPP to further reduce the uncertainty in model parameters.

\subsection{Approach and Scope}

Fifteen creep tests were performed on clean and argillaceous salt at temperatures of either $25^{\circ} \mathrm{C}$ or $100^{\circ} \mathrm{C}$ and stress differences between $3.5 \mathrm{MPa}$ and $21.0 \mathrm{MPa}$. All tests were performed under a confining pressure of 15.0 MPa. Table 1-1 gives the test matrix. Eight of the tests were performed on argillaceous salt, and the remaining seven were performed on clean salt. Test duration ranged from 23 to 613 days to produce upper bound estimates of the steady-state strain rate. The test conditions given in Table 1-1 are similar to those previously imposed on specimens from the WIPP site.

Table 1-1. Test Matrix

\begin{tabular}{ccc}
\hline & \multicolumn{2}{c}{ Temperature $\left({ }^{\circ} \mathrm{C}\right)$} \\
\cline { 2 - 3 }$(\mathrm{MPa})$ & 25 & 100 \\
\hline 3.5 & & $\mathrm{~A}, \mathrm{C}$ \\
5.0 & & $\mathrm{~A}, \mathrm{~A}, \mathrm{C}$ \\
7.0 & & $\mathrm{C}$ \\
11.5 & $\mathrm{~A}, \mathrm{C}{ }^{(2)}$ & \\
13.0 & $\mathrm{~A}$ & \\
15.0 & $\mathrm{~A}, \mathrm{~A}, \mathrm{~A}, \mathrm{C}$ & \\
17.0 & $\mathrm{C}$ & \\
21.0 & $\mathrm{C}$ & \\
\hline (a) $\mathrm{A}-$ Argillaceous, C - Clean
\end{tabular}

The steady-state strain rate and transient strain limit for each test are the primary results from these tests. Values obtained are compared with those obtained previously. 


\subsection{Report Organization}

The remainder of this report is organized into four chapters and two appendixes. The next chapter, Chapter 2, describes the specimens tested in this study. Chapter 3 describes the testing machines and test procedures used, while Chapter 4 gives the test results. Chapter 5 gives conclusions of this test program and is followed by a list of references. Two appendixes that give strain-versus-time curves for the individual creep tests conclude the report. Appendix A gives curves for clean specimens, and Appendix B gives curves for argillaceous specimens. 


\subsection{SPECIMENS}

\subsection{Sample Acquisition and Description}

Horizontally-oriented, 0.4-m-diameter specimen stock was dry (air) cored from the ribs of several of the test rooms at the WIPP. The argillaceous salt was sealed after drilling to preserve the natural moisture content of the clays. The clean salt was not sealed because no significant amounts of clay minerals were present. The specimens were placed in boxes or mounted on pallets and shipped to Rapid City via truck.

\subsection{Specimen Preparation}

Specimens were prepared by subcoring the $0.4-\mathrm{m}$-diameter core samples. The core samples were sawn dry using a large bandsaw to produce rectangular prisms. These prisms were then subcored using saturated brine to obtain 100-mm-diameter, 200-mm-long specimens whose axes were vertical (normal to the bedding). Specimen ends were machined flat and parallel within $.015 \mathrm{~mm}$ in a lathe using a collet and carbide tooling.

Argillaceous specimens were immediately sealed by wrapping in Saran Wrap, then aluminum foil, and dipping in a polymer wax. They remained sealed until they were jacketed for testing. Clean specimens were sealed in plastic bags.

Each specimen was assigned an identification number according to WIPP Procedure No. 092 and logged into the RE/SPEC specimen inventory along with its dimensions.

\subsection{Jacketing}

Specimens for triaxial tests were jacketed to prevent the confining pressure fluid from entering the pore space. Initially, the specimer was inspected for any pits that may have resulted from coring. These pits were filled with a silicone sealant to prevent jacket intrusion under pressure. The specimen was then placed between cylindrical steel platens with a molybdenum disulfide dry lubricant placed in the specimen-to-steel interfaces. Two lengths of 1.6-mm-thick Viton tubing were then slipped over the assembly and sealed to each platen with steel lock wires. The Viton jacket could withstand temperatures of $200^{\circ} \mathrm{C}$. 


\subsection{TESTING MACHINES}

\subsection{Load Frames}

Figure 3-1 presents a cross section of a typical load frame for creep testing with prominent components labeled for reference. The machines use a single-ended, triaxial pressure vessel that accommodates a 100-mm-diameter cylindrical specimen having a length-to-diameter ratio of $L: D=2: 1$. A hydraulic cylinder bolted to the base of the load frame drives the loading piston, which applies axial compressive force to the specimen. Hydraulic pressure is supplied by a nitrogen-charged accumulatc. Confining pressure is applied to the jacketed specimen by pressurizing the sealed vessel chamber with silicone oil. A dilatometer system maintains constant confining pressure and provides the volumetric measurement for making lateral strain calculations.

The testing machines can apply compressive axial loads up to $1.5 \mathrm{MN}$ and confining pressures up to $70 \mathrm{MPa}$. The heating system, including seals on the pressure vessel, can maintain specimen temperatures up to $200^{\circ} \mathrm{C}$.

A control panel houses the accumulators, hydraulic pumps, pressure intensifiers, transducer signal conditioners, temperature controllers, and confining pressure controllers for two adjacent test frames. The panels contain digital meters that display the output of the transducers. The temperature controller gives a digital output of the temperature. Mechanical pressure gages mounted in the panel give readings of the nitrogen pressure in the accumulator and the oil pressure in the hydraulic cylinder.

\subsection{Instrumentation}

Axia: force is measured by a load cell in the load train outside the pressure vessel, while confining pressure is measured by a pressure transducer in the line between the intensifier and the pressure vessel. Temperature is measured by a thermocouple in the wall of the pressure vessel. The relationship between specimen temperature and that recorded by this thermocouple has been determined by calibration runs at several temperatures that span the operating range. Axial deformation in the specimen is measured by two Linear Variable Differential Transformers (LVDTs) mounted outside the pressure vessel. They monitor displacement of the loading piston relative to the bottom of the pressure vessel; and during data reduction, their output is corrected 


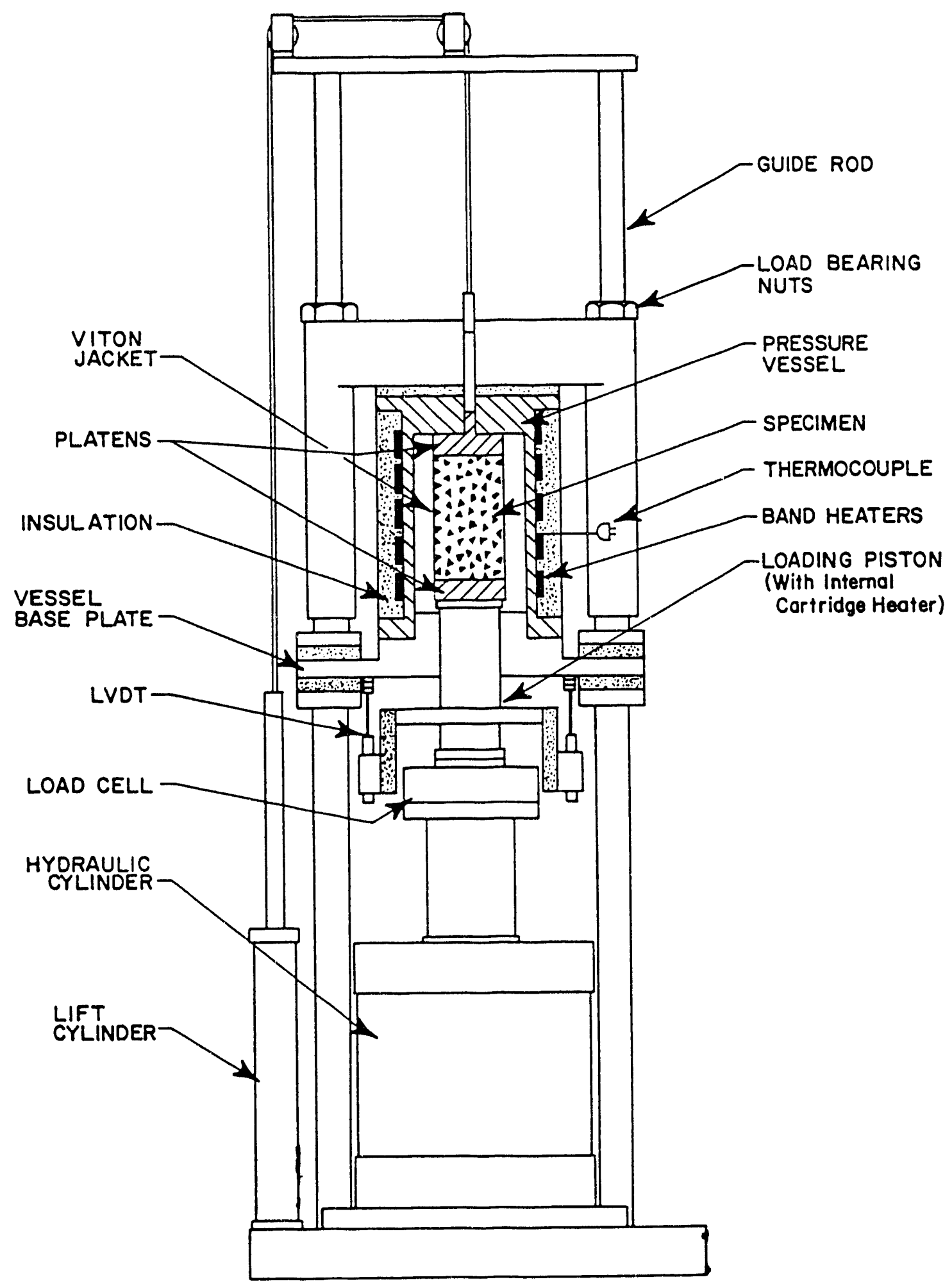

Figure 3-1. Test machine load frame. 
to account for test machine deformation. Lateral deformation is measured using a dilatometer. With this technique, lateral deformation is determined at fixed pressure by measuring the volume of oil that the intensifier withdraws from the pressure vessel, and then by compensating for the axial deformation measured by the LVDTs. A rotary potentiometer is mounted on the intensifier shaft to provide a signal that is proportional to the volume of oil that is withdrawn from the pressure vessel.

\subsection{Calibration}

The transducers used to collect data are calibrated following standard RE/SPEC laboratory procedures and using standards traceable to the U.S. National Institute of Standards and Technology. Transducer accuracy is verified before and after each test. The calibration goals are to obtain measurements that are as accurate as possible within the constraints imposed by instrument drift over the long durations of the creep tests. The initial transducer accuracy for load and pressure measurements was always within 1 percent of the reading, deformations were accurate within 2 percent of reading, and temperature accuracy was within $2^{\circ} \mathrm{C}$. Resolution of the measurements is based on a 14-bit analog-to-digital converter having one bit for sign.

Before the tests were started, all the test systems met the accuracy verification guidelines. After the tests were completed, post-test accuracy verification for transducer calibrations were beyond the initial accuracy determination limits for five tests. The post-test verification of the confining pressure transducer used to test Specimen L4X01-6/1-2/1-4/1 showed accuracy within 2.4 percent of reading. On Specimen L4X01-6/1-1/1-1/1, the post-test accuracy of the load cell was verified at 2 percent of reading. The post-test lateral strain system accuracy was 5 percent of reading for Specimen L4X01-5/1-1/1-7/1. The load cell used for Specimen C1X01-1/3-3/6-1 showed a post-test error of just over 1 percent of reading, and on Specimen C1X01-1/3-3/4-1, the load cell verification showed an error of about 2.2 percent of reading. These final accuracies, even for the five tests noted, are all within acceptable limits for salt creep data. The data for all the creep tests have been used in the analyses performed in this report without further reference to the accuracy limitations. 


\subsection{Control}

Temperature is controlled with a manual set-point controller that controls power to both the band heaters on the vessel and the cartridge heater in the piston. The thermocouple in the pressure vessel wall supplies the feedback signal. The specimen temperature is maintained constant within $0.2^{\circ} \mathrm{C}$. Confining pressure is controlled by inputting the pressure transducer signal to a unit that contains two manual set points. These set points are adjusted to maintain the confining pressure constant within $20 \mathrm{kPa}$. When a set point is reached, the controller signals the dilatometer intensifier to advance or retreat, depending upon whether the lower or upper set point has been reached. Axial load is controlled by a Digital Equipment Corporation PDP-11/23 microcomputer. The computer determines the current cross-sectional area of the specimen from the outputs of the deformation transducers and then adjusts the load to maintain constant stress. The deadband on load under computer control is $0.4 \mathrm{kN}$, and for 100 -mm-diameter specimens, gives a deadband on axial stress of $50 \mathrm{kPa}$.

\subsection{Test Procedures and Data Acquisition}

The constant stress (creep) tests are initiater by the operator, but are controlled by a PDP $11 / 23$ computer. When conducting a triaxial compression test, a hydrostatic stress equal to the confining pressure is initially applied to the specimen, and the dilatometer servosystem is actuated to maintain constant pressure. The system is then allowed to stabilize. Elevated temperature tests are then heated to the desired temperature. Next, the operator inputs the specimen dimensions, as well as the confining pressure and desired axial stress, and the computer outputs the axial load required to obtain the axial stress, assuming no change in specimen diameter. The operator increases the axial load to this value within 15 to 20 seconds, using the panel meter display as feedback, and then immediately gives control of the test to the computer. The computer, which has monitored specimen deformation under operator loading, immediately increases the load to give the desired stress. The computer monitors specimen deformation and the axial force every 60 seconds and adjusts the force, if necessary, to maintain constant stress throughout the test. Axial force is adjusted using two solenoid valves that, when opened, either add nitrogen to the accumulator or vent nitrogen from it. The data channels are scanned at a selectable rate, typically every 15 seconds. Data are saved according to one of two criteria. First, if the specimen length changes by a prescribed amount since the last data were logged, data are logged again. If, however, the specimen length changes by less than the prescribed amount over a time selected by the operator, data are logged at the end of this time period. Typical logging criteria for rate and length change are two hours and $0.02 \mathrm{~mm}$, respectively. 


\subsection{TEST RESULTS}

\subsection{Strain-Versus-Time Curves}

Figure 4-1 shows typical axial strain and lateral strain-versus-time curves obtained from each of the fifteen tests performed. The reported strains are total specimen strains which include the elastic and inelastic strains induced during loading to the required stress level. The strain measures are logarithmic (or natural) with compression signed positive. The axial strain-versus-time curves obtained are smooth, with little scatter of data in nearly every test. The lateral strain-versus-time curves are smooth for specimens that experienced relatively large deformations (axial strains greater than about 1 percent); however, the lateral strain measurements at smaller deformations are much less reliable because of small leaks that may occur in the dilatometer system. As noted in Section 3.1, the dilatometer system provides the volumetric measurement for making lateral strain calculations so small leaks will cause the magnitude of the lateral deformation to be underestimated. The strain-versus-time curves show the expected decelerating transient, which is followed by apparent steady deformation. In some of the tests, the steady deformation rate was followed by an increase in deformation rate near the completion of the test which may indicate that the tertiary creep mode had been entered. In a few tests on argillaceous salt, the deformation showed an accelerating transient near the beginning of the test, which was followed by normal decelerating transient or steady-state creep. Deviations such as this were attributed to possible consolidation of the clay concentrations characteristic of the argillaceous salt.

Tests were terminated for any of three reasons. The first is based on a precedent set by Senseny (1986) that the specimen be limited to an axial strain of approximately 0.135 , including the strain produced by loading. Axial deformations of this magnitude are usually accompanied by lateral deformations large enough so that the specimen diameter becomes larger than the platen causing an inhomogeneous stress and strain distribution in the specimen. The second reason to terminate a creep test is that the estimate of steady-state strain rate does not change appreciably over several months. Estimation of the steady-state strain rate is discussed later in Section 4.2. The third reason to terminate a test is that a power outage or equipment malfunction occurs.

The durations of the fifteen tests ranged from 23 days to 613 days and the average test duration was 300 days. The test conditions covered a range of axial stress differences and two temperature levels. The lowest axial stress difference was $3.5 \mathrm{MPa}$ while the highest was 21.0 


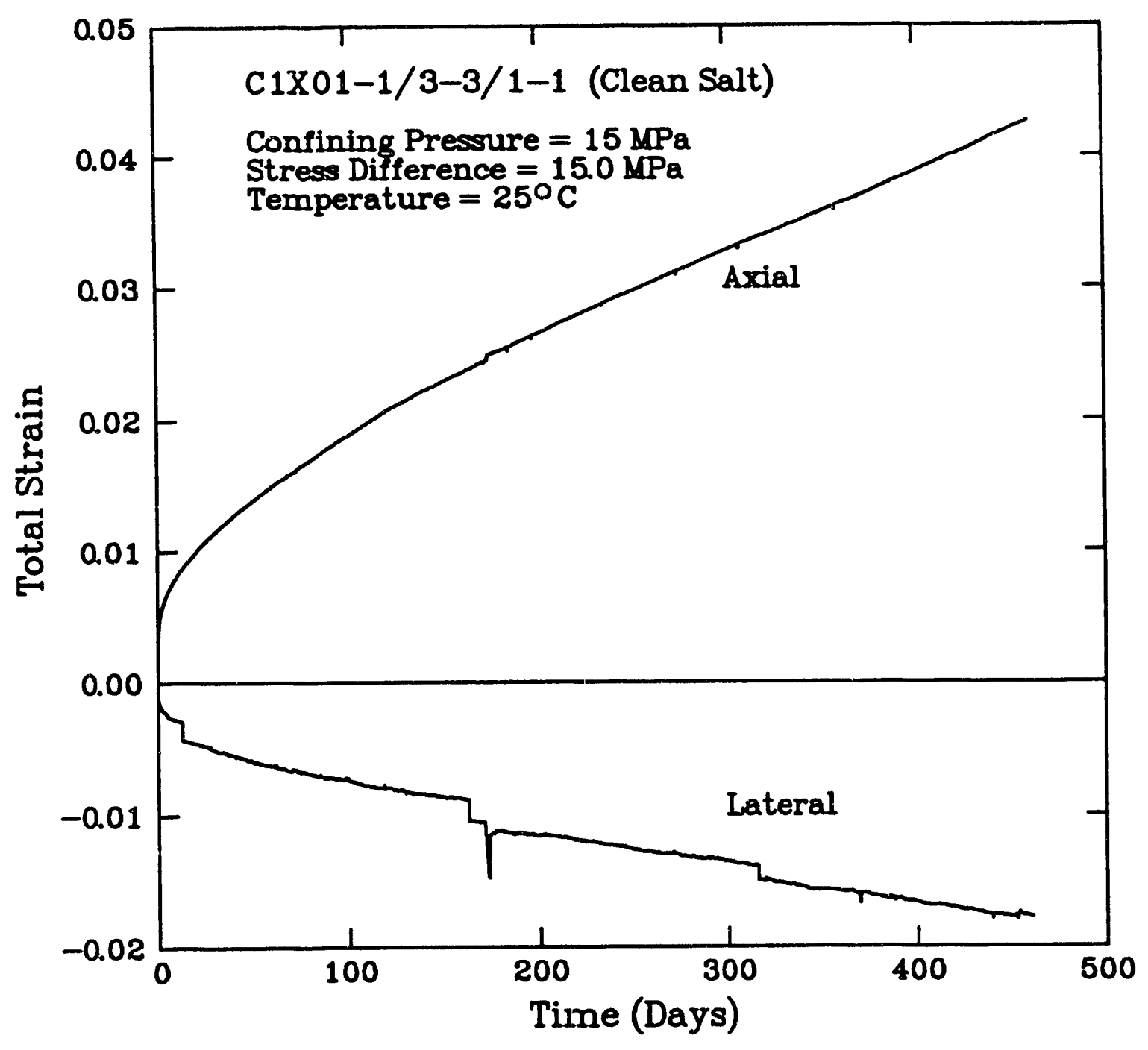

AS1-078-84-068

Figure 4-1. Typical strain-versus-time curves for WIPP salt. 
$\mathrm{MPa}$. Test temperatures were set at either $25^{\circ} \mathrm{C}$ or $100^{\circ} \mathrm{C}$. The ccnfining pressure in all tests was $15 \mathrm{MPa}$. Appendix A gives strain-versus-time curves for each of the seven tests on clean specimens, and Appendix B gives similar curves for each of the eight tests on argillaceous specimens.

\subsubsection{Clean Salt}

All tests exhibited the normal (concave downward) loading transient creep response with the exception of three tests on clean salt which exhibited accelerating strain rates. Two cases occurred near the completion of the test (tertiary creep) and one occurred during the early time of the creep test. The two tests that exhibited tertiary creep behavior were performed at temperature and stress conditions of $\left\{25^{\circ} \mathrm{C}, 21 \mathrm{MPa}\right\}$ and $\left\{100^{\circ} \mathrm{C}, 3.5 \mathrm{MPa}\right\}$. The strain-versus-time curves for these two tests are shown in Figures A-4 and A-5, respectively. The tertiary response that appeared at $\left\{25^{\circ} \mathrm{C}, 21 \mathrm{MPa}\right\}$ occurred at a strain level of about 11 percent and may have resulted from an inhomogeneous stress state created by nonuniform lateral displacements at such high strains. The tertiary response in the test at $\left\{100^{\circ} \mathrm{C}, 3.5 \mathrm{MPa}\right\}$ occurred at a very low strain level of about 0.35 percent approximately 1 year after the test had been started. This point in time roughly corresponds to a series of power outages in the laboratory which resulted in loss of laboratory temperature control for a short time and loss of computer control of the test. The coincidence of the tertiary response with the restarting of the test after loss of power may indicate that the response was driven by the change in laboratory temperature or loss of computer control.

The third test exhibiting accelerating strain rate was run at $\left\{100^{\circ} \mathrm{C}, 7 \mathrm{MPa}\right\}$ and developed a concave upward strain response at early test times as shown in Figure A-7. After about 3 weeks, the strain response slowed and became steady. This was the only clean salt specimen that exhibited this type of behavior. Similar anomalous results have been reported for clean salt from the DX16 and DX19 core (Senseny, 1986) and no complete explanation has been offered.

\subsubsection{Argillacesus Salt}

Two tests on argillaceous salt produced an accelerating strain rate at early test times. Both tests were performed at a stress difference of $5 \mathrm{MPa}$ and temperature of $100^{\circ} \mathrm{C}$. One of the tests had a duration of about 70 days and the other test duration was over 400 days. The strain-versus-time curves for these tests are given in Figure B-7 and B-8, respectively. Both tests 
started normally, but after a short time the deformation accelerated. The long duration test produced strain-versus-time curves that were concave upward for about the first month, and then the deformation slowed and started to accumulate at a decreasing rate producing a typical concave-downward strain-versus-time curve leading to a steady-strain rate. In the shorter duration test, the deformation rate appears to have also accelerated for about a month and then directly approaches a steady-strain rate.

\subsection{Fitting Parameters}

All 15 tests exhibited a linear strain-time response during a portion of the test. This linear response was interpreted as steady-state creep deformation. Typically, the most linear part of the curve occurs near the end of the test. Accelerating deformation (sometimes observed at either early times or near the completion of the test) is ignored. Two fitting parameters were determined for each test by determining the slope and intercept of the line defined by either the minimum slope attained or the minimum slope at the inflection point of the creep curve. The slope of the line represents the steady-state strain rate and the intercept gives a value which is the sum of the elastic loading strain and the inelastic transient strain limit. The transient strain limit is easily determined by subtracting the elastic loading strains from the intercept value. The elastic loading strains are simply the applied axial stress difference divided by the Young's modulus which is $31 \mathrm{GPa}$ as reported by Munson et al. (1988).

Tables 4-1 and 4-2 give specimen identification, temperature, stress difference, transient strain limit, and steady-state strain rate information for the clean and argillaceous salts, respectively. The tables contain data from both the current study and also from previous work done on WIPP salt. The previous studies are referenced in the tables and comprise work done by Senseny $(1986,1990)$ and Hansen and Mellegard (1979) as summarized by Munson and Dawson (1979). In these previous studies, triaxial compression creep tests were performed on WIPP salt at test temperatures of $22,24,70,100$, and $200^{\circ} \mathrm{C}$, and stress differences ranging from 6.4 to $41.4 \mathrm{MPa}$. The test machines in the current study are similar to those used in previous studies of WIPP salt, and specimen preparation and test procedures were also very similar. A notable exception is that the Hansen and Mellegard (1979) data were generated using 50-mm-diameter specimens and the other data shown in the tables are from 100-mm-diameter specimens. If size effects are negligible, the test results should be comparable. The transient strain limits reported in Tables 4-1 and 4-2 are sometimes larger than those reported in the original references because the inelastic loading strains have been included here. 
Table 4-1. Steady-State Strain Rates and Transient Strain Limits for Clean Salt

\begin{tabular}{|c|c|c|c|c|c|}
\hline $\begin{array}{c}\text { Test } \\
\text { Identification }\end{array}$ & $\begin{array}{c}\text { Temperature } \\
\left({ }^{\circ} \mathrm{C}\right) \\
\end{array}$ & $\begin{array}{l}\sigma_{1} \cdot \sigma_{3} \\
(\mathbf{M P a})\end{array}$ & 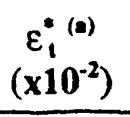 & $\begin{array}{c}\varepsilon_{\mathrm{II}}^{\mathbf{( b )}} \\
\left(\times 10^{-10} \mathrm{~s}^{-1}\right) \\
\end{array}$ & $\begin{array}{c}\text { Reference }^{(\mathrm{e})} \\
\text { Code }\end{array}$ \\
\hline $\mathrm{C} 1 \mathrm{X} 01-1 / 3-3 / 7-1$ & 25 & 11.5 & 0.45 & 1.10 & a \\
\hline C1X01-1/3-3/1-1 & 25 & 15.0 & 1.40 & 7.20 & $\mathbf{a}$ \\
\hline C $1 \times 01-1 / 3-3 / 4-1$ & 25 & 17.0 & 2.11 & 21.00 & a \\
\hline $\mathrm{C} 1 \mathrm{X} 01-1 / 3-3 / 2-1$ & 25 & 21.0 & 4.11 & 60.00 & $\mathbf{a}$ \\
\hline C1X01-1/3-3/6-1 & 100 & 3.5 & 0.20 & 0.48 & a \\
\hline C1X01-1/3-2/7-1 & 100 & 5.0 & 0.21 & 3.00 & $\mathrm{a}$ \\
\hline MCE36-1/1-1/2-2/2 & 100 & 7.0 & 0.42 & 25.00 & a \\
\hline$D \times 16-2 / 7-1-2$ & 25 & 10.0 & 0.21 & 0.66 & b \\
\hline DX 19-5/7-1-2 & 25 & 10.0 & 0.30 & 0.45 & b \\
\hline DX 19-5/5-1-2 & 25 & 13.0 & 0.83 & 2.30 & b \\
\hline DX16-2/1-1-2 & 25 & 15.0 & 0.91 & 11.00 & b \\
\hline DX 16-2/4-1-2 & 25 & 17.0 & 1.51 & 23.00 & b \\
\hline DX16-2/8-1-2 & 25 & 19.0 & 3.64 & 34.00 & b \\
\hline DX19-5/6-1-2 & 25 & 19.0 & 2.35 & 40.00 & $\mathrm{~b}$ \\
\hline DX16-2/6-1-2 & 25 & 21.0 & 3.65 & 57.00 & $\mathrm{~b}$ \\
\hline DX19-5/1-1-2 & 25 & 25.0 & 5.50 & 200.00 & $\mathrm{~b}$ \\
\hline DX19-5/2-1-2 & 25 & 30.0 & 7.94 & 590.00 & $\mathrm{~b}$ \\
\hline DX19-5/3-1-2 & 25 & 30.0 & 6.83 & 590.00 & b \\
\hline$D \times 16-2 / 3-1-2$ & 100 & 3.5 & 0.08 & 1.30 & $\mathrm{~b}$ \\
\hline DX19-4/4-1-2 & 100 & 7.0 & 1.19 & 40.00 & b \\
\hline DX19-5/4-1-2 & 100 & 17.0 & 5.95 & 3100.00 & b \\
\hline DX16-2/2-1-2 & 200 & 2.0 & 0.04 & 4.30 & b \\
\hline DX16-2/5-1-2 & 200 & 2.0 & 0.07 & 9.10 & b \\
\hline DX19-4/3-1-2 & 200 & 3.5 & 4.71 & 270.00 & b \\
\hline
\end{tabular}

(a) $\varepsilon_{\mathrm{t}}^{*}=$ Transient strain limit

(b) $\varepsilon_{I I}^{s}=$ Steady-state strain rate. Subscript II refers to the second characteristic portion of a theoretical strain-versus-time creep curve.

(c) Reference Sources:

$\mathrm{a}=$ Current Work

$\mathrm{b}=$ Senseny, 1986

$c=$ Senseny, 1990

$\mathrm{d}=$ Munson \& Dawson, 1979 
Table 4-1. Steady-State Strain Rates and Transient Strain Limits for Clean Salt (continued)

\begin{tabular}{|c|c|c|c|c|c|}
\hline $\begin{array}{c}\text { Test } \\
\text { Identification } \\
\end{array}$ & $\begin{array}{c}\text { Temperature } \\
\left({ }^{\circ} \mathrm{C}\right)\end{array}$ & $\begin{array}{l}\sigma_{1}-\sigma_{3} \\
(\mathbf{M P a})\end{array}$ & $\begin{array}{c}\varepsilon_{l}^{*(\omega)} \\
\left(\mathbf{x 1 0 ^ { - 2 }}\right)\end{array}$ & $\begin{array}{c}\varepsilon_{11}^{3}{ }^{(b)} \\
\left(\times 10^{-10} s^{-1}\right)\end{array}$ & $\begin{array}{c}\text { Reference }^{(\mathrm{e})} \\
\text { Code }\end{array}$ \\
\hline ERDA9/88/2124-0/1 & 25 & 11.7 & 0.69 & 1.00 & c \\
\hline ERDA9/88/2126-0/1 & 25 & 15.0 & 1.45 & 6.60 & c \\
\hline ERDA9/88/2127-0/1 & 25 & 10.0 & 0.33 & 0.39 & c \\
\hline C $1 \times 01-02 / 1-3 / 1-2$ & 25 & 15.0 & 1.30 & 3.50 & c \\
\hline C1X01-04/1-3/1-2 & 25 & 10.0 & 0.43 & 0.76 & $\mathrm{c}$ \\
\hline C1X01-04/1-3/2-2 & 25 & 15.0 & 1.28 & 6.80 & $\mathrm{c}$ \\
\hline $9-2655$ & 22 & 8.3 & 0.13 & 1.40 & $\mathrm{~d}$ \\
\hline $9-2677$ & 22 & 7.9 & 0.13 & 0.80 & $d$ \\
\hline $7-2777$ & 22 & 33.1 & 6.47 & 3100.00 & $d$ \\
\hline $9-2672.5$ & 100 & 6.9 & 0.78 & 100.00 & d \\
\hline $9-2624$ & 100 & 7.2 & 0.92 & 81.00 & d \\
\hline $9-2686$ & 100 & 6.9 & 0.15 & 25.00 & d \\
\hline $9-2671$ & 100 & 6.4 & 0.21 & 18.00 & d \\
\hline $9-2688$ & 200 & 6.9 & 2.16 & 1500.00 & d \\
\hline $9-2668$ & 200 & 6.9 & 3.50 & 2000.00 & d \\
\hline $9-2078$ & 22 & 13.8 & 0.25 & 4.20 & d \\
\hline $9-2083$ & 22 & 20.3 & 1.53 & 16.00 & $d$ \\
\hline $9-2078.5$ & 22 & 11.7 & 0.11 & 1.20 & d \\
\hline $9-2083.5$ & 22 & 20.0 & 1.13 & 23.00 & $d$ \\
\hline 14 & 24 & 41.4 & $\mathrm{n} / \mathrm{a}$ & 4800.00 & d \\
\hline 2 & 70 & 10.3 & $n / a$ & 140.00 & d \\
\hline 6 & 70 & 20.7 & $\mathrm{n} / \mathrm{a}$ & 4100.00 & d \\
\hline 3 & 100 & 10.3 & $\mathrm{n} / \mathrm{a}$ & 380.00 & $d$ \\
\hline 8 & 100 & 10.3 & $\mathrm{n} / \mathrm{a}$ & 410.00 & $d$ \\
\hline 7 & 100 & 20.7 & $\mathrm{n} / \mathrm{a}$ & 15000.00 & $d$ \\
\hline 12 & 100 & 20.7 & $\mathrm{n} / \mathrm{a}$ & 42000.00 & d \\
\hline
\end{tabular}
(a) $\varepsilon_{i}^{*}=$ Transient strain limit
(b) $\varepsilon_{\mathrm{n}}^{s}=$ Steady-state strain rate. Subscript II refers to the second characteristic portion of a theoretical strain-versus-time creep curve.
(c) Reference Sources:
$\mathrm{a}=$ Current Work
$\mathrm{b}=$ Senseny, 1986
$\mathrm{c}=$ Senseny, 1990
$\mathrm{d}=$ Munson \& Dawson, 1979
(d) $\mathbf{n} / \mathbf{a}=$ not available. 
Table 4-2. Steady-State Strain Rates and Transient Strain Limits for Argillaceous Salt

\begin{tabular}{|c|c|c|c|c|c|}
\hline $\begin{array}{c}\text { Test } \\
\text { Identification }\end{array}$ & $\begin{array}{c}\text { Temperature } \\
\left({ }^{\circ} \mathrm{C}\right)\end{array}$ & $\begin{array}{l}\sigma_{1}-\sigma_{3} \\
(\mathrm{MPa})\end{array}$ & $\begin{array}{c}\varepsilon_{l}^{*}(a) \\
\left(\mathbf{x 1 0}^{-2}\right)\end{array}$ & $\begin{array}{c}\varepsilon_{\text {II }}^{3}(\text { b) } \\
\left(\mathbf{x 1 0}^{-10} \mathrm{~s}^{-1}\right)\end{array}$ & $\begin{array}{c}\text { Reference }^{(c)} \\
\text { Code }\end{array}$ \\
\hline$L 4 X 01-6 / 1-2 / 1-2 / 1$ & 25 & 15.0 & 2.33 & 5.00 & $\mathbf{a}$ \\
\hline$L 4 X 01-6 / 1-2 / 1-4 / 1$ & 25 & 11.5 & 3.06 & 19.0 & a \\
\hline L4X01-6/1-1/1-1/1 & 25 & 13.0 & 2.04 & 8.30 & a \\
\hline L4X01-6/1-1/1-2/1 & 25 & 15.0 & 1.26 & 40.00 & a \\
\hline L4X01-5/1-1/1-7/1 & 25 & 15.0 & 6.17 & 81.00 & a \\
\hline L4X01-5/1-1/1-3/1 & 100 & 3.5 & 0.09 & 7.10 & a \\
\hline L4X01-6/1-2/1-7/1 & 100 & 5.0 & 0.00 & 47.00 & $\mathbf{a}$ \\
\hline L4X01-7/1-2/1-4/1 & 100 & 5.0 & 1.67 & 20.00 & a \\
\hline$P 4 X 18-4 / 4-1-2$ & 25 & 10.0 & 0.38 & 1.10 & $\mathrm{~b}$ \\
\hline $\mathrm{P} 4 \mathrm{X} 18-1 / 5-1-2$ & 25 & 10.0 & 1.05 & 1.70 & b \\
\hline$P 4 X 18-1 / 3-1-2$ & 25 & 15.0 & 2.27 & 250.00 & b \\
\hline $\mathrm{P} 4 \mathrm{X} 18-4 / 2-1-2$ & 25 & 15.0 & 1.12 & 13.00 & $\mathrm{~b}$ \\
\hline$P 4 X 18-1 / 6-1-2$ & 25 & 21.0 & 3.63 & 110.00 & b \\
\hline $\mathrm{P} 4 \mathrm{X} 18-4 / 1-1-2$ & 100 & 3.5 & 0.09 & 5.40 & b \\
\hline $\mathrm{P} 4 \mathrm{X} 18-2 / 3-1-2$ & 100 & 7.0 & 0.90 & 120.00 & $\mathrm{~b}$ \\
\hline $\mathrm{P} 4 \mathrm{X} 18-4 / 5-1-2$ & 200 & 2.0 & 0.88 & 10.00 & $\mathrm{~b}$ \\
\hline $\mathrm{P} 4 \mathrm{X} 18-2 / 4-1-2$ & 200 & 3.5 & 3.21 & 310.00 & b \\
\hline \multicolumn{6}{|c|}{$\begin{array}{l}\text { (a) } \varepsilon_{\mathrm{t}}^{*}=\text { Transient strain limit } \\
\text { (b) } \varepsilon_{\mathrm{I}}^{\mathrm{s}}=\text { Steady-state strain rate. Su } \\
\text { a theoretical strain-versus-time } \\
\text { (c) Reference Sources: } \\
\mathrm{a}=\text { Current Work } \\
\mathrm{b}=\text { Senseny, } 1986 \\
\mathrm{c}=\text { Senseny, } 1990 \\
\mathrm{~d}=\text { Munson \& Dawson, } 1979\end{array}$} \\
\hline
\end{tabular}

Figures 4-2 and 4-3 plot both previous and current strain rate-versus-stress results shown in Tables 4-1 and 4-2 for clean and argillaceous salt, respectively. In these plots, the ordinate is the base 10 logarithm of the steady-state strain rate, and the abscissa is the base 10 logarithm of the stress difference from the tables divided by the shear modulus, $\mu$, of salt. The value of $\mu$ used is $12.4 \mathrm{GPa}$, as reported by Munson et al. (1989). 


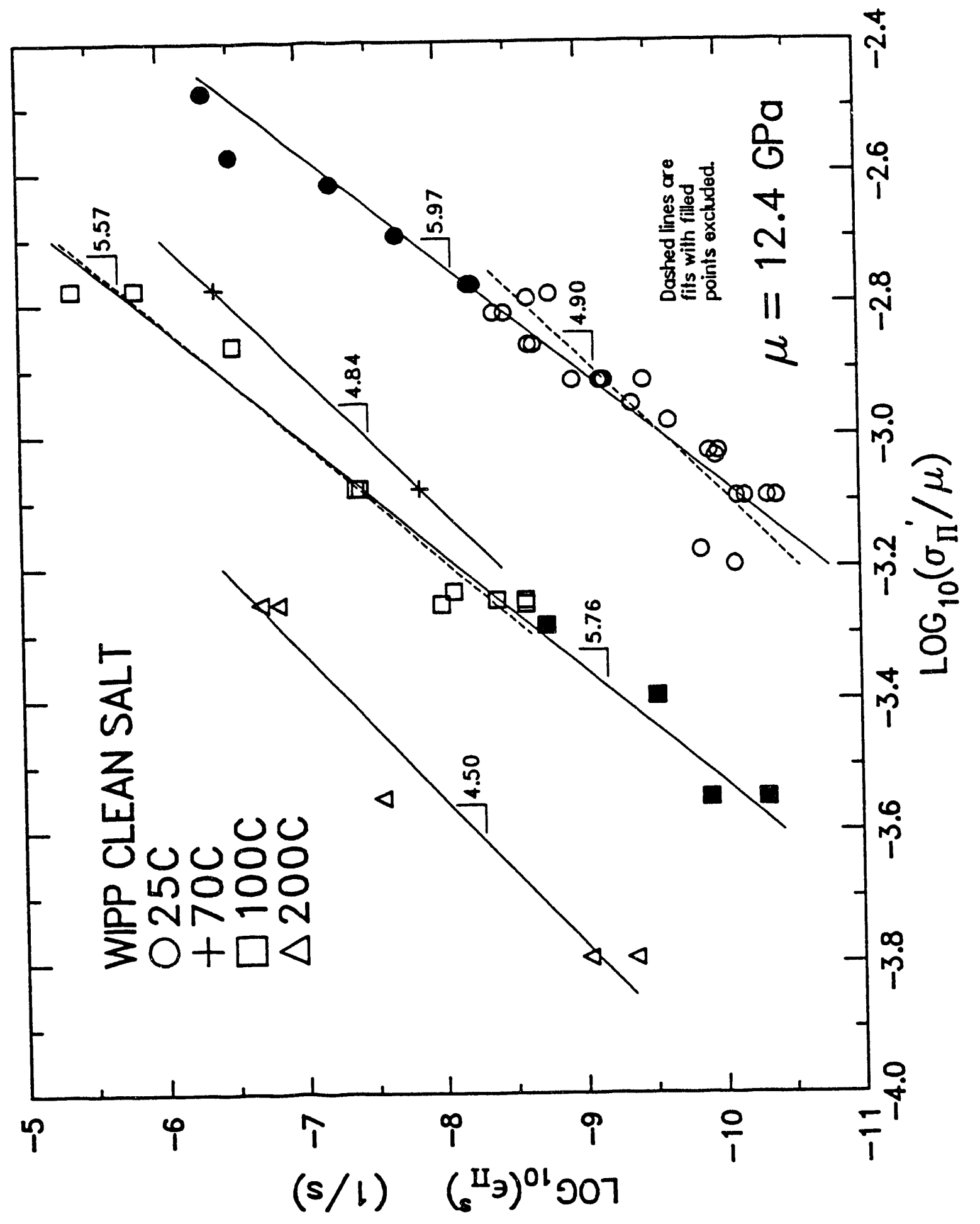

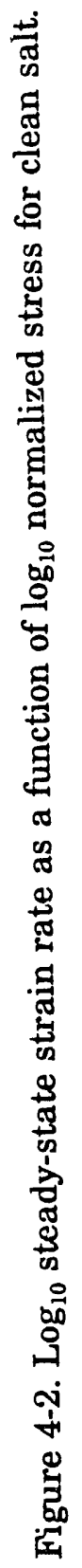




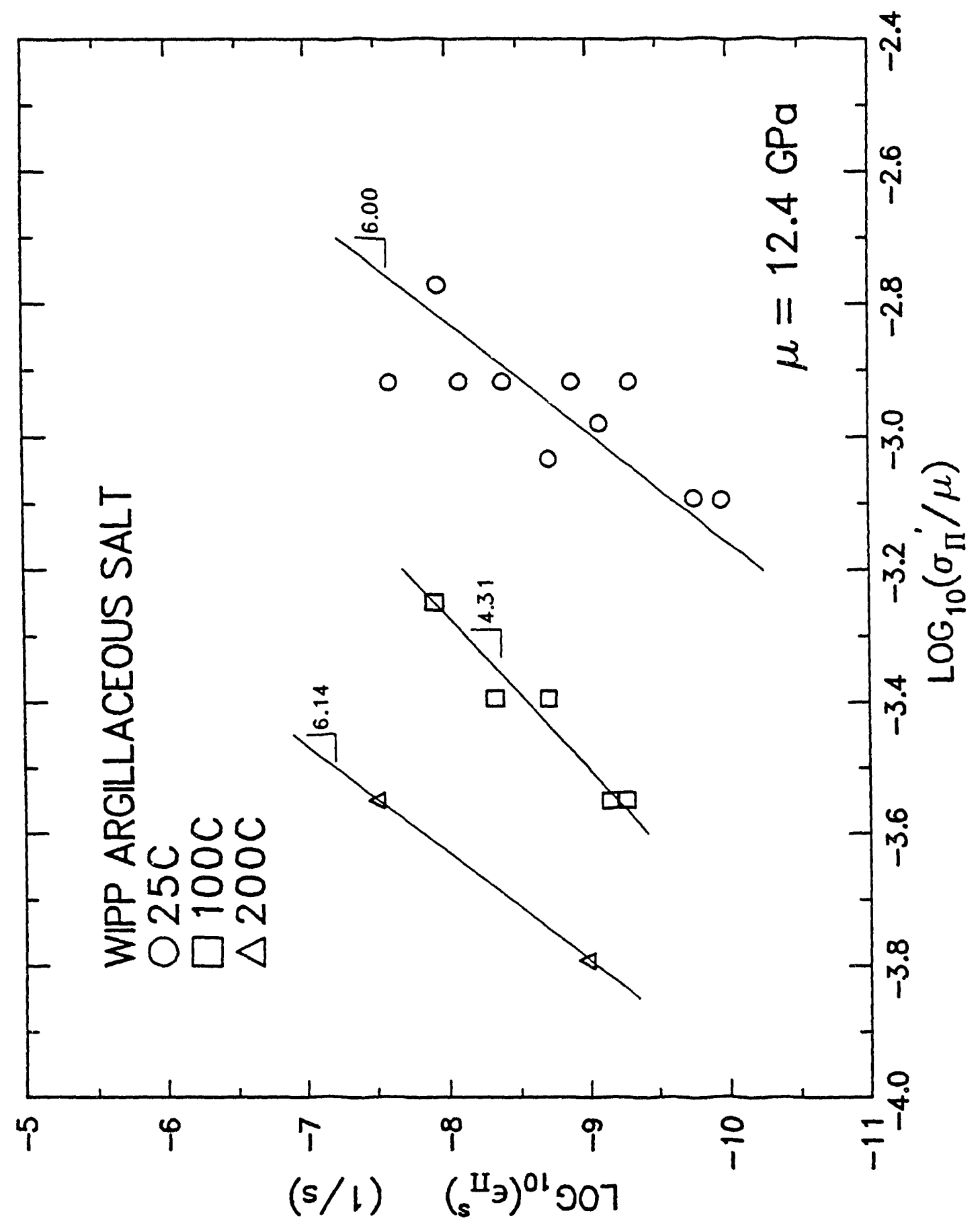

荡 
For the clean salt shown in Figure 4-2, most of the data that falls within the undefined mechanism regime is at a temperature of $25^{\circ} \mathrm{C}$. Seven of the twenty-nine data points at $25^{\circ} \mathrm{C}$ actually lie outside the boundaries of the undefined mechanism because they are at a stress difference of $20.7 \mathrm{MPa}$ or greater which is the boundary stress that separates the undefined mechanism from the dislocation glide mechanism. The seven data points are identified as filled circles on Figure 4-2. The seven test identification labels are C1X01-1/3-3/2-1, DX16-2/6-1-2, DX19-5/1-1-2, DX19-5/2-1-2, DX19-5/3-1-2, 7-2777, and 14. When a linear least squares fit is made to all twenty-nine data points generated at $25^{\circ} \mathrm{C}$, the undefined mechanism stress exponent determined by the slope of the line is 5.97 , which is nearly 20 percent higher than the published value of 5.0 (Munson et al. 1988). If the seven tests in the glide regime are excluded from the linear regression fit, the stress exponent becomes 4.9 , which is much closer to the reported value of 5.0 for the undefined mechanism.

Most of the clean salt data that falls within the dislocation climb regime is at a temperature of $100^{\circ} \mathrm{C}$. If a linear least squares fit is made to all fourteen data points at $100^{\circ} \mathrm{C}$, the stress exponent for the dislocation climb mechanism is found to be 5.76 which is about 5 percent higher than the reported value of 5.5. In this case there are four tests that lie outside the boundary of the dislocation climb regime because they are at or below a stress level of $6.5 \mathrm{MPa}$, which separates the undefined mechanism from the dislocation climb mechanism at $100^{\circ} \mathrm{C}$. The four data points are identified as filled squares on Figure 4-2. The four test identification labels are C1X01-1/3-3/6-1, CiX01-1/3-2/7-1, DX16-2/3-1-2, and 9-2671. If these four tests are excluded from the linear regression fit, the stress exponent becomes 5.57 which is very close to the reported value of $\mathbf{5 . 5}$ for the dislocation climb mechanism.

For the argillaceous salt shown in Figure 4-3, all ten of the data points at $25^{\circ} \mathrm{C}$ were used to determine the stress dependence of the undefined mechanism. As shown in the figure, the slope of the fitted line is 6.0 and there is considerably more scatter in the data than was seen in the results for clean salt. The value of 6.0 is 9 percent larger than the published value of 5.5 , but is not regarded as extremely dissimilar considering the large amount of scatter. There were too few data points available to make any further analyses of the stress dependence of argillaceous salt.

A summary of the fits made to determine the values of the stress exponents is given in Table 4-3. The table gives the number of data points used to make each fit at the various temperatures for both clean and argillaceous salt.

Figures 4-4 and 4-5 plot transient strain limit as a function of stress for argillaceous and clean salt, respectively. The abscissa is the same as for the steady-state strain rate plots, while 
Table 4-3. Summary of Stress Exponent Determinations for WIPP Salt

\begin{tabular}{|c|c|c|c|c|}
\hline \multirow{2}{*}{$\begin{array}{c}\text { Temperature } \\
\left({ }^{\circ} \mathrm{C}\right)\end{array}$} & \multicolumn{2}{|c|}{ Clean } & \multicolumn{2}{|c|}{ Argillaceous } \\
\hline & Exponent & No. of Pts. & Exponent & No. of Pts. \\
\hline 25 & 5.97 & 29 & 6.00 & 10 \\
\hline $25^{(a)}$ & $4.90^{(a)}$ & $22^{(2)}$ & & \\
\hline 70 & 4.84 & 2 & - & - \\
\hline 100 & 5.76 & 14 & 4.31 & 5 \\
\hline $100^{(\mathbf{b})}$ & $5.57^{(\mathrm{b})}$ & $10^{(\mathrm{b})}$ & & \\
\hline 200 & 4.50 & 5 & 6.14 & 2 \\
\hline
\end{tabular}

(a) Includes only stress states within undefined mechanism regime.

(b) Includes only stress states within dislocation climb mechanism regime.

the ordinate is the base 10 logarithm of the transient strain limit. The transient strain limit includes the inelastic strain induced during application of the stress difference required by the creep test but not the el stic load-up strain. In order that all the data be consistent, these inelastic load-up strains were included for the tests previously reported.

From theoretical considerations, tive slope of a linear fit in Figures 4-4 and 4-5 should have a slope of three (Munson and Dawson, 1979). The scatter in the argillaceous salt which presumably is caused by the clay impurities and the accelerating transient strain responses seen in somte tests results in a much wider range of fitted slopes. There is insufficient data bott. in range of stresses and number of tests to make any statement that would contradict the theoretical value of three for the slope of the fitted lines. The greatest number of data points has been generated for cleari salt at a temperature of $25^{\circ} \mathrm{C}$ (Figure 4-4) and the fitted line gives a slope of 3.05 which agrees with the theoretical value. There are far fewer data at other temperatures for clean salt, but the fitted curves give values that reasonably agree with the theoretical value.

The scatter in the data make comparison of the clean and argillaceous salts rather tenuous. However, a comparison of the two salt types can be made by examining the stress exponents determined at $25^{\circ} \mathrm{C}$ within the undefined mechanism regime as shown previously in Table 4-3. The stress exponent determined for clean salt was 4.90 , which represents a fitted slope from a 


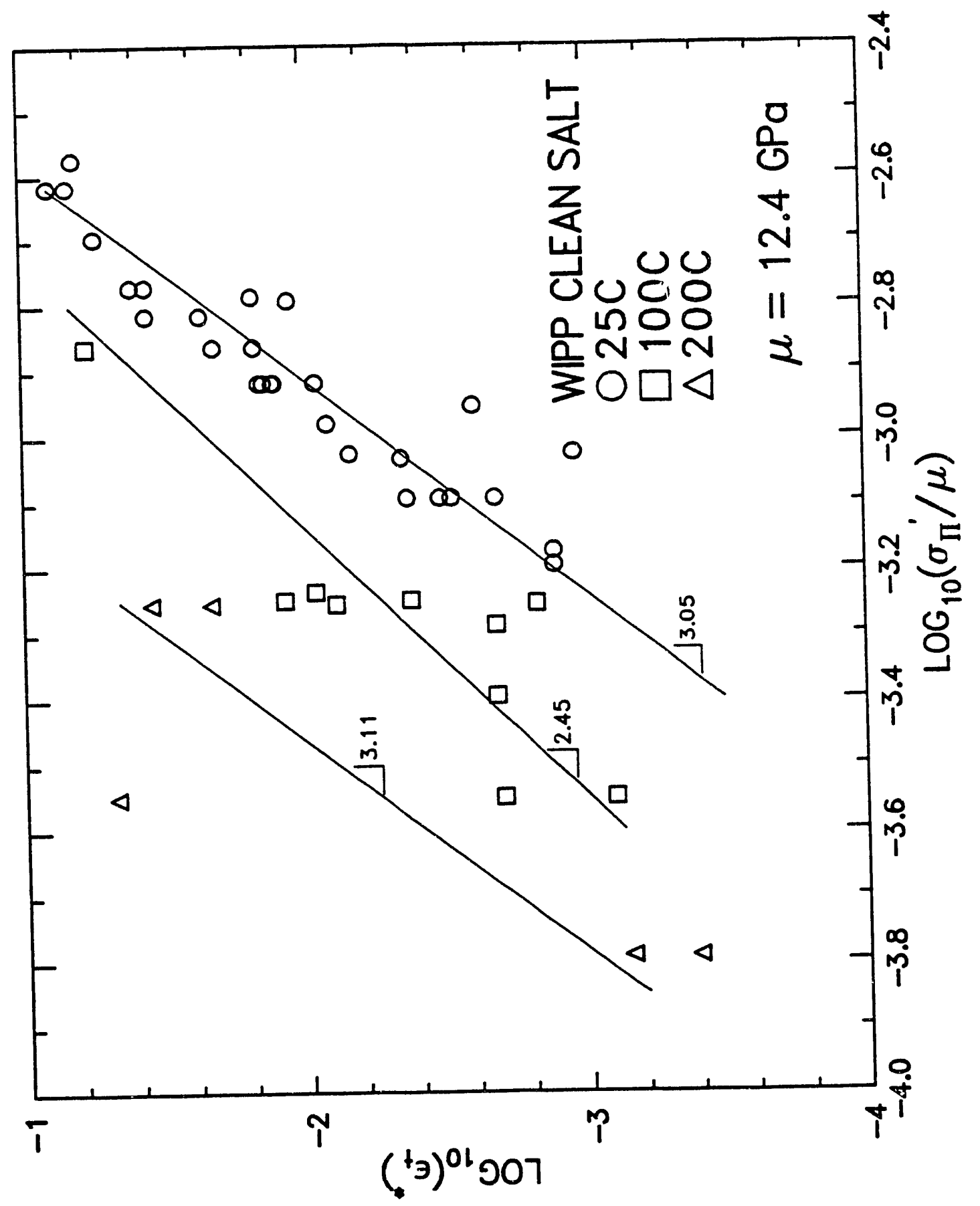



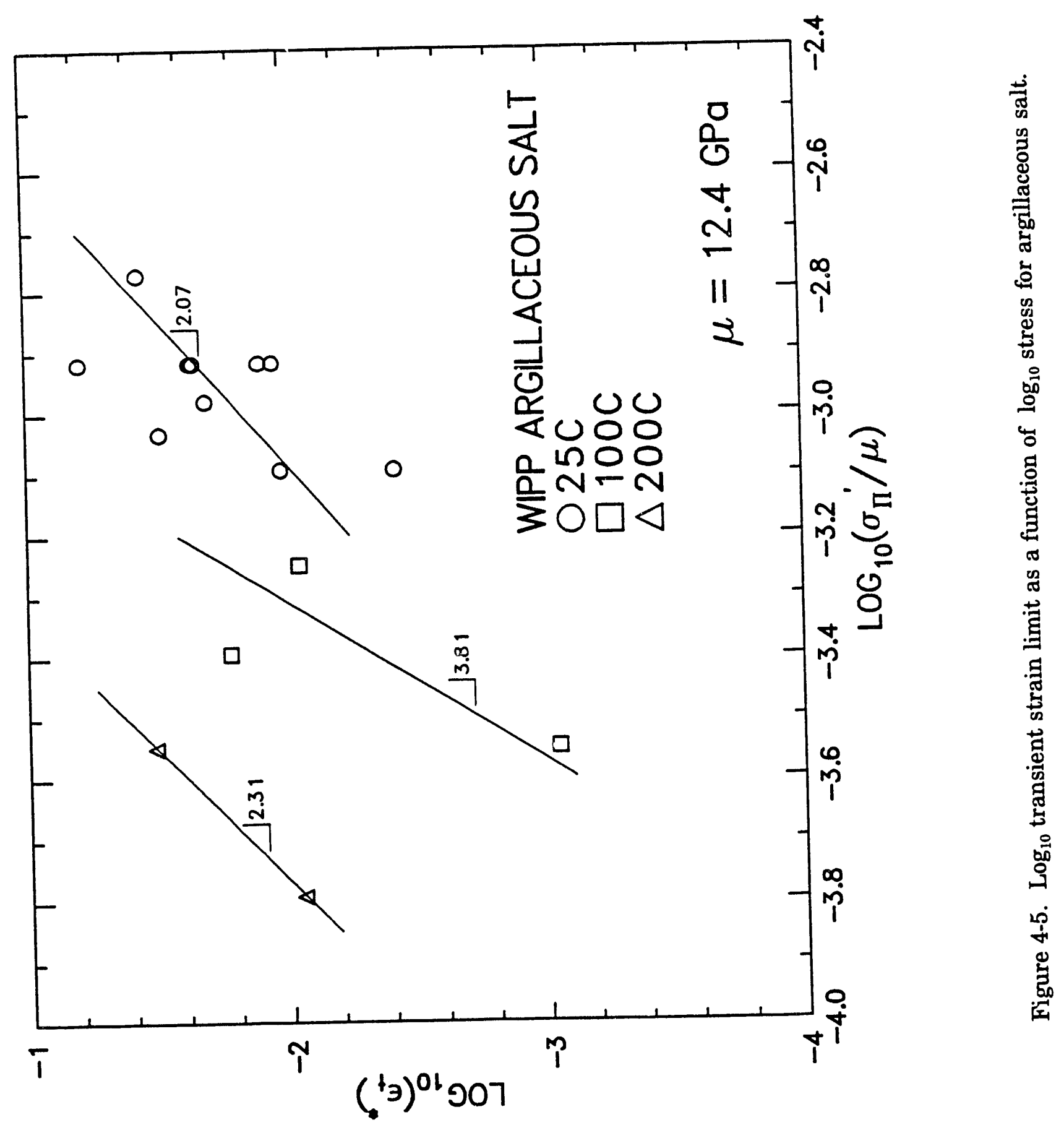
linear regression based on 22 data points. This fitted slope had an estimated standard deviation of 0.4794 . Similarly, the stress exponent of 6.0 for the argillaceous salt was determined from a fitted slope based on 10 points and the estimated standard deviation was 1.845. A comparison of the 1 standard deviation confidence intervals on the two salt types showed that the clean salt interval (4.42 to 5.34) does overlap the argillaceous salt interval (4.16 to 7.85). Therefore, no strong statistical claim can be made that the stress dependence of the two salt types differs at $25^{\circ} \mathrm{C}$ within the undefined mechanism regime. This result should be used with caution since the steady-state strain rates determined from straight-edge fits were used directly without qualification in the statistical analyses. It is known that estimates of the steady-state-strain rate from larger relatively short duration tests are biased to values larger than the "true" steady-state rate. No attempt was made to remove this bias from the statistical analysis because of the limited data available. The bias could be removed by performing additional long duration tests so that good estimates of the steady-state rate could be determined. These additional estimates could be substituted for estimates from shorter tests and the statistical analysis performed again. 


\subsection{CONCLUSIONS}

Fifteen triaxial compression creep tests were performed on salt from the WIPP site to supplement the existing database. Both argillaceous and clean salt were tested at temperatures of 25 and $100^{\circ} \mathrm{C}$, and at stress differences between 3.5 and $21 \mathrm{MPa}$. The durations of the fifteen tests ranged from 23 days to 613 days and the average test duration was 300 days. These durations were long enough to obtain estimates of the steady-state strain rate and transient strain limit.

In general, results of these tests are similar to those obtained previously. By combining the current results with previous results, twenty-two data points were used to determine a stress exponent of 4.9 for the undefined mechanism in clean salt. This value is very close to the published value of 5.0. Similarly, by combining previous and current results, ten data points were used to determine a stress exponent of 5.57 for the dislocation climb mechanism in clean salt. This value is also very close to the published value of 5.5 .

The argillaceous salt displayed a significant amount of scatter in all test results. However, enough data were centered at $25^{\circ} \mathrm{C}$ to compare the stress dependence of argillaceous salt to that of clean salt. Using one standard deviation, it was found that the interval for the higher stress exponent value of 6.0 determined for argillaceous salt overlapped the interval determined for the clean salt value of 4.9. The high level of uncertainty in the argillaceous result precluded making any strong statistical statement about the differences between the stress dependence of the two salt types.

The published value of the stress dependence of the transient strain limit was compared to the data and could not be contradicted. In fact, the data at $25^{\circ} \mathrm{C}$ for clean salt gave a value of 3.05 which agrees with the theoretical value of three. Additional testing over a broader range of stresses would be necessary to examine the transient strain limit stress dependence for argillaceous salt. Replicate tests of argillaceous salt would also allow a better assessment of the true variability being encountered in argillaceous salt. 


\subsection{REFERENCES}

Hansen, F.D. and K.D. Mellegard. 1979. Creep Behavior of Bedded Salt from Southeastern New Mexico at Elevated Temperature. SAND79-7030. Albuquerque, NM: Sandia National Laboratories.

Munson, D.E. , A.F. Fossum, and P.E. Senseny. 1989. Advances in Resolution of Discrepancies Between Predicted and Measured In Situ WIPP Room Closures. SAND88-2948. Albuquerque, NM: Sandia National Laboratories.

Munson, D.E. and P.R. Dawson. 1984. "Salt Constitutive Modeling Using Mechanism Maps," Proceedings, First Conference on the Mechanical Behavior of Salt. Eds. H.R. Hardy and M. Langer. Federal Republic of Germany: Trans Tech Publications, Clausthal-Zellerfeld. 718-737.

Munson, D.E. and P.R. Dawson. 1982a. A Transient Creep Model for Salt During Stress Loading and Unloading. SAND82-0962. Albuquerque, NM: Sandia National Laboratories.

Munson, D.E. and P.R. Dawson. 1982b. " A Workhardening/Recovery Model of Transient Creep of Salt During Stress Loading and Unloading," Proceedings, 23rd U.S. Symposium on Rock Mechanics, August. University of California, Berkeley, CA: 299-306.

Munson, D.E. and P.R. Dawson. 1979. Constitutive Model for the Low Temperature Creep of Salt (With Application to WIPP). SAND79-1853. Albuquerque, NM: Sandia National Laboratories.

Munson, D.E. 1979. Preliminary Deformation-Mechanism Map for Salt (With Application to WIPP). SAND79-0076. Albuquerque, NM: Sandia National Laboratories.

Senseny, P.E. 1990. Creep of Salt From the ERDA-9 Borehole and the WIPP Workings. SAND89-7098. Albuquerque, NM: Sandia National Laboratories.

Senseny, P.E. 1986. Triaxial Compression Creep Tests on Salt From the Waste Isolation Pilot Plant. SAND85-7261. Albuquerque, NM: Sandia National Laboratories. 


\section{APPENDIX A}

\section{CLEAN SALT}

A-1 
A-2 


\section{FIGURES}

A-1. Axial (top) and lateral (bottom) strain as a function of time for Specimen C1X01-1/3-3/7-1.............................. A $\ldots \ldots$

A-2. Axial (top) and lateral (bottom) strain as a function of time for Specimen C1X01-1/3-3/1-1........................... A

A-3. Axial (top) and lateral (bottom) strain as a function of time for Specimen C1X01-1/3-3/4-1. . . . . . . . . . . . . . . . . . . . . A-7

A-4. Axial (top) and lateral (bottom) strain as a function of time for Specimen C1X01-1/3-3/2-1............................. A-8

A-5. Axial (top) and lateral (bottom) strain as a function of time for Specimen C1X01-1/3-3/6-1............................. A-9

A-6. Axial (top) and lateral (bottom) strain as a function of time for Specimen C1X01-1/3-2/7-1........................... A-10

A-7. Axial (top) and lateral (bottom) strain as a function of time for Specimen MCE36-1/1-1/2-2/2. . . . . . . . . . . . . . . . . . . . A-11 
A-4 


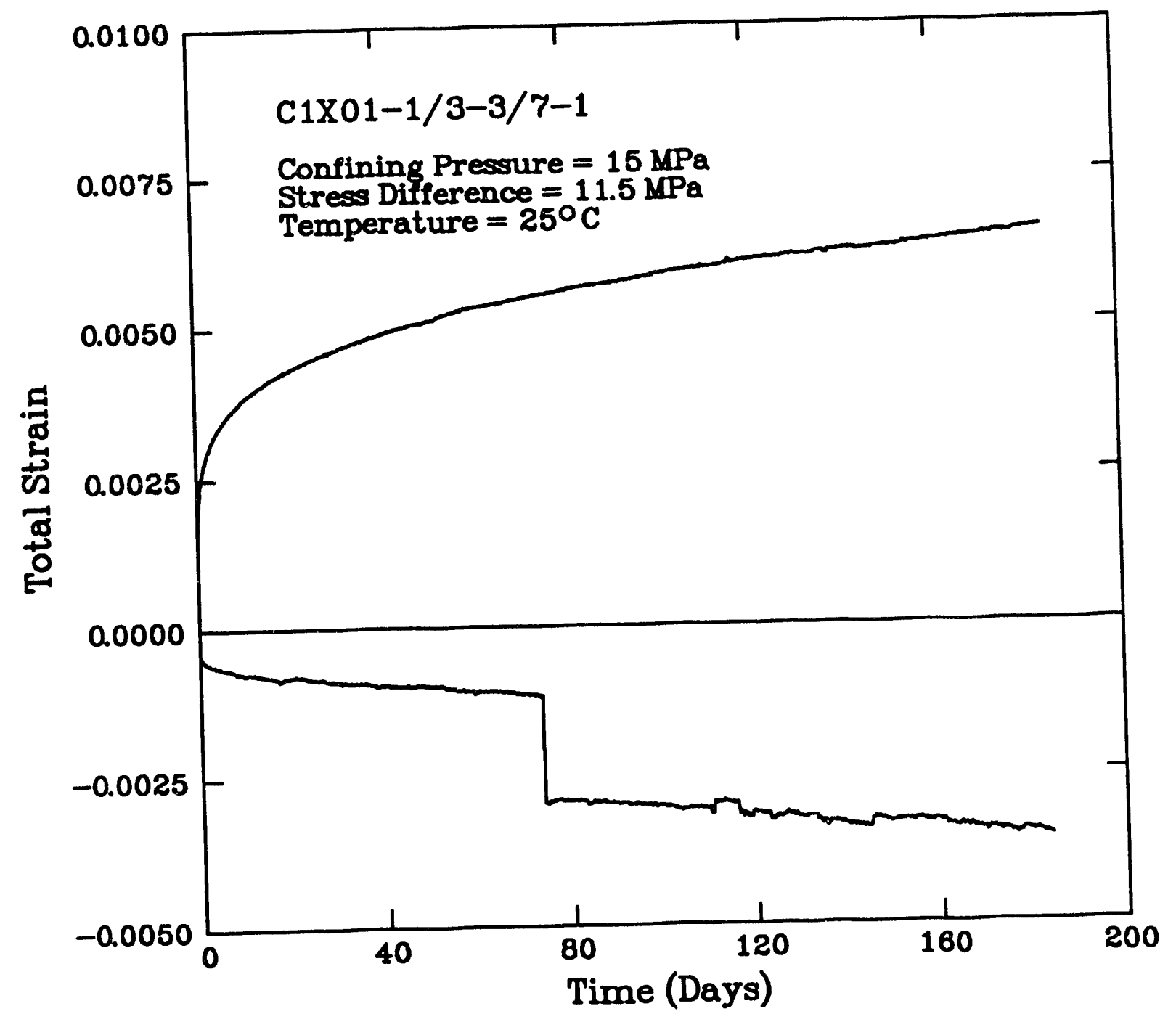

PSI-144-91-05

Figure A-1. Axial (top) and lateral (bottom) strain as a function of time for Specimen C1X01-1/3-3/7-1. 


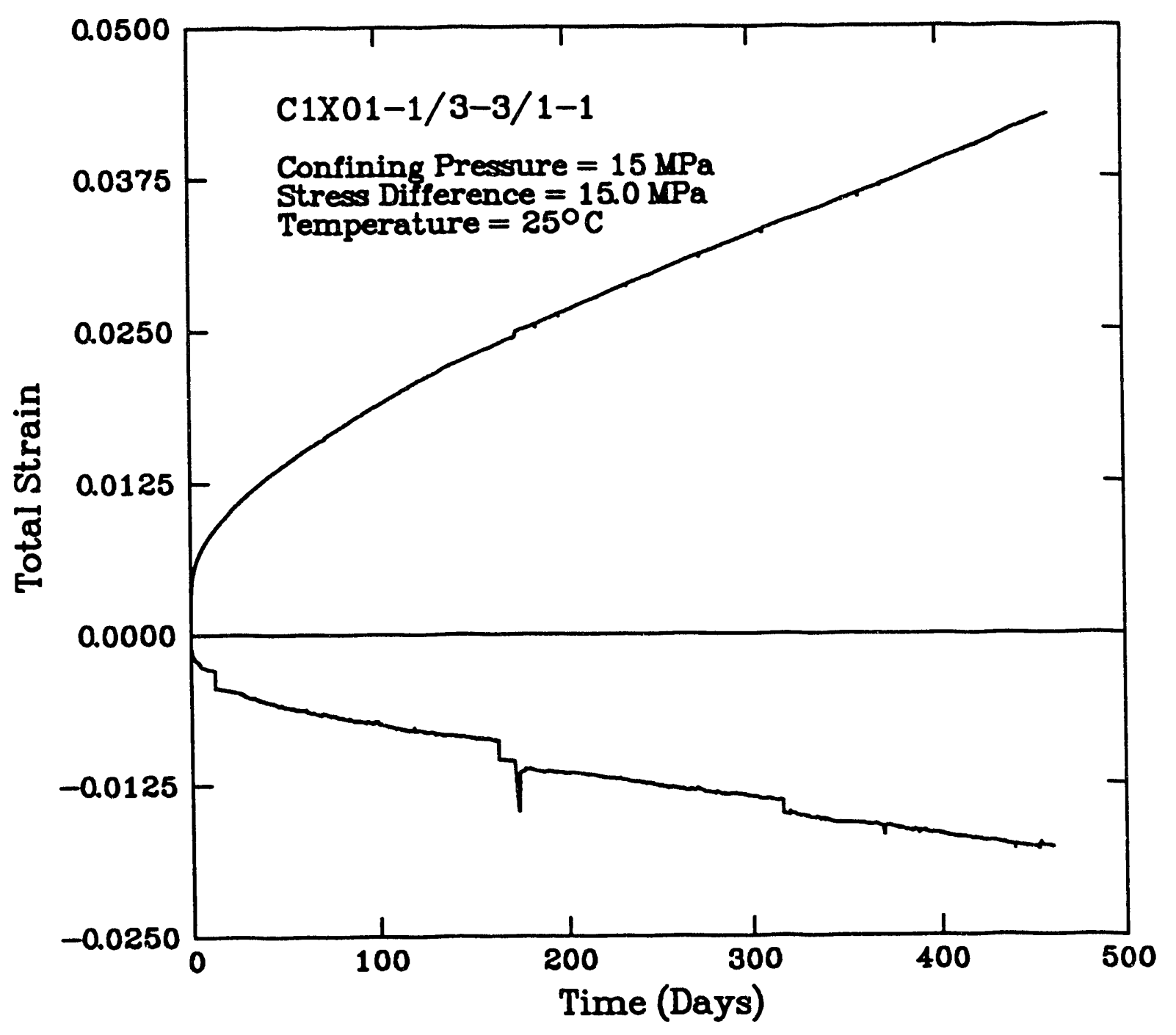

PSI-144-91-06

Figure A-2. Axial (top) and lateral (bottom) strain as a function of time for Specimen C1X01-1/3-3/1-1. 


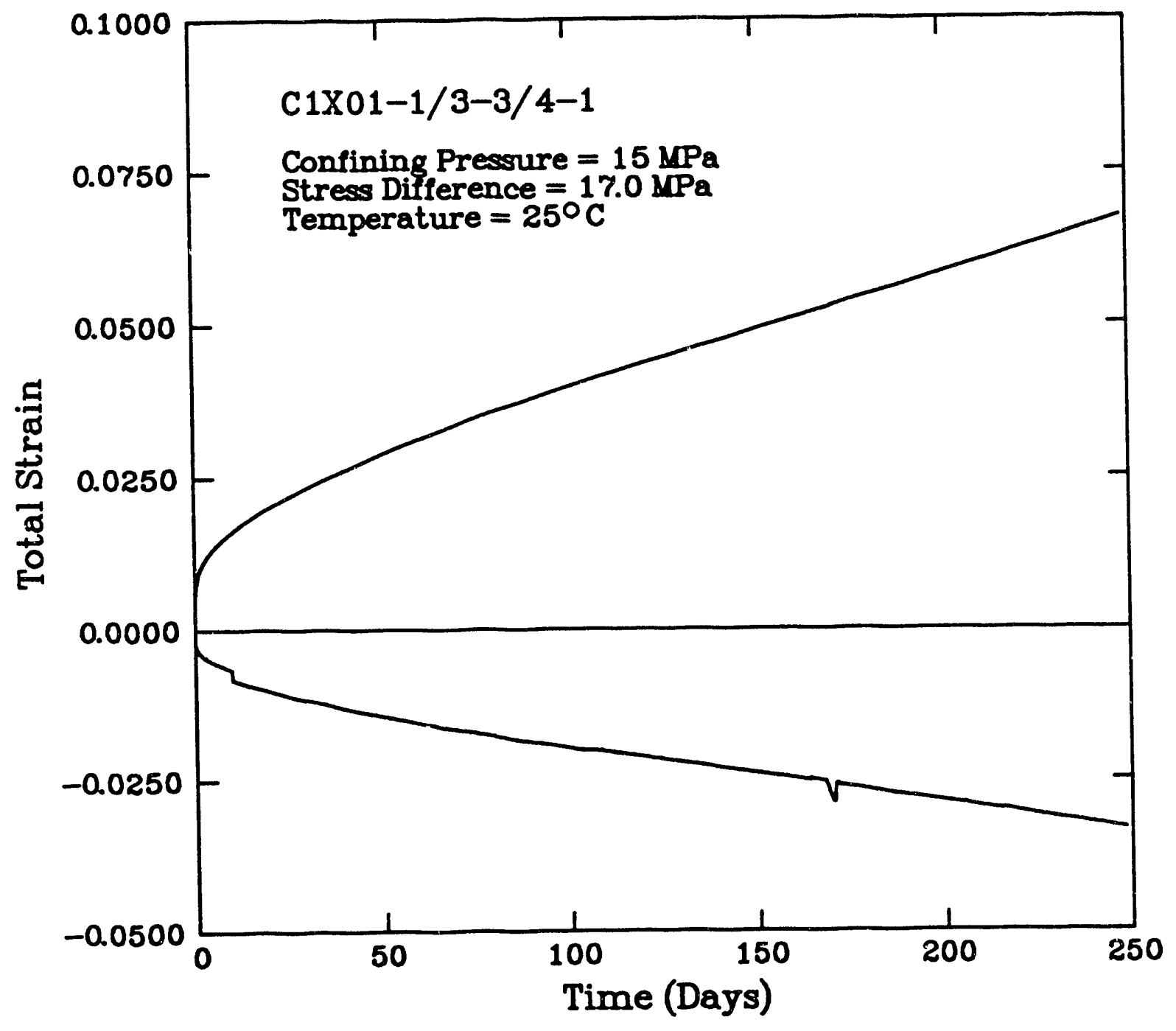

AS1-144-91-07

Figure A-3. Axial (top) and lateral (bottom) strain as a function of time for Specimen C1X01-1/3-3/4-1. 


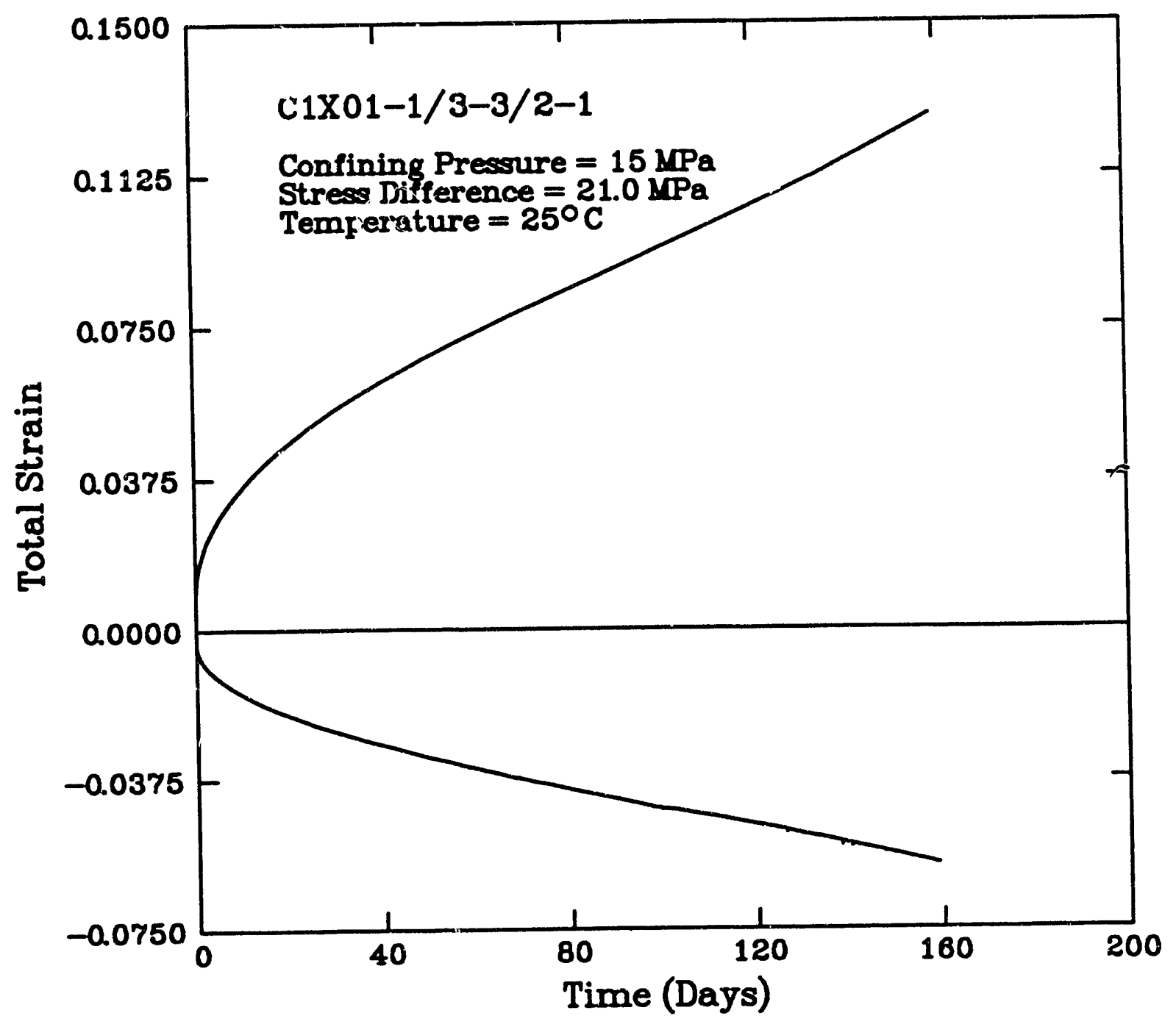

Figure A-4. Axial (top) and lateral (bottom) strain as a function of time for Specimen C1X01-1/3-3/2-1. 


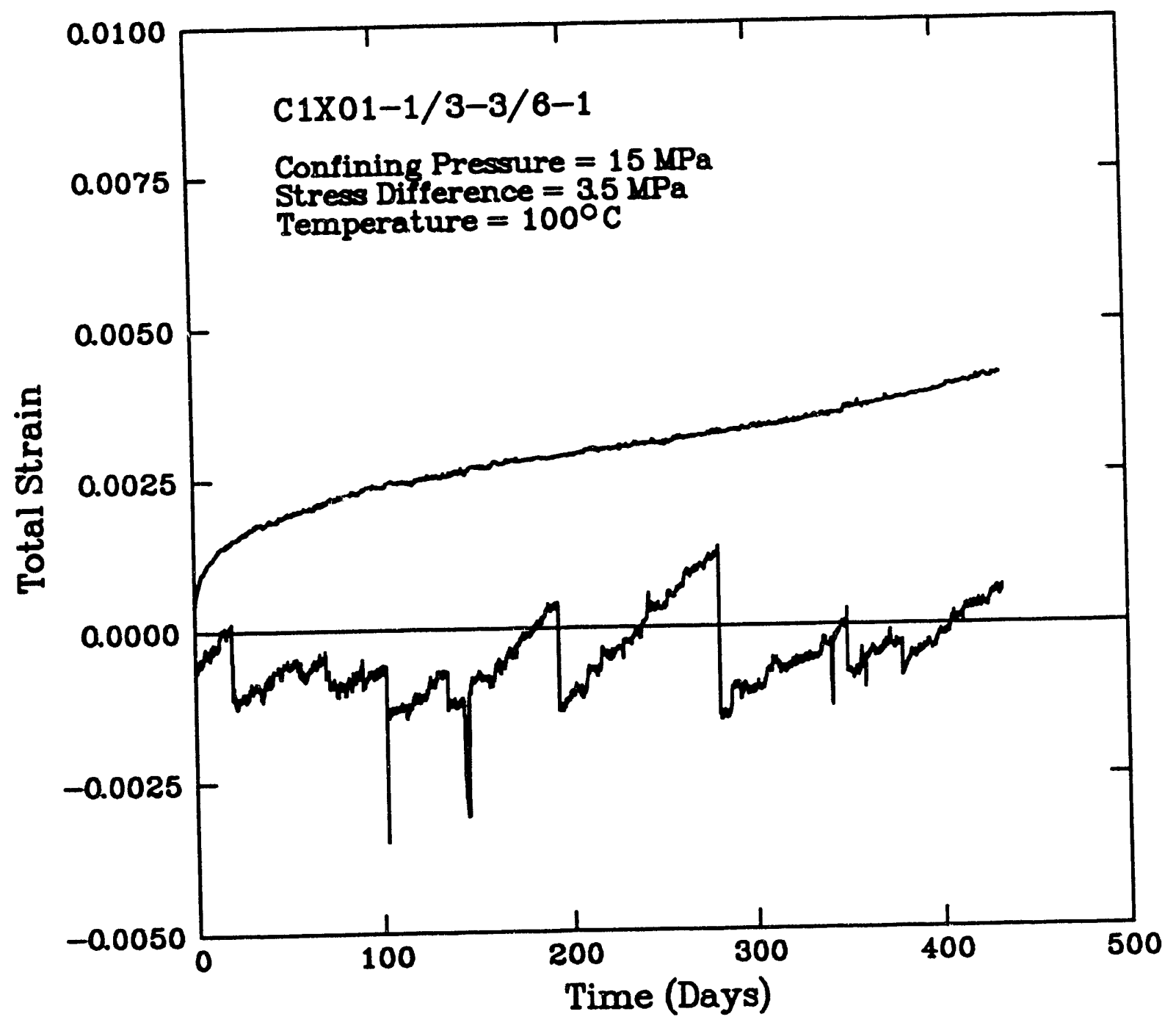

RSI.144-91-09

Figure A-5. Axial (top) and lateral (bottom) strain as a function of time for Specimen C1X01-1/3-3/6-1. 


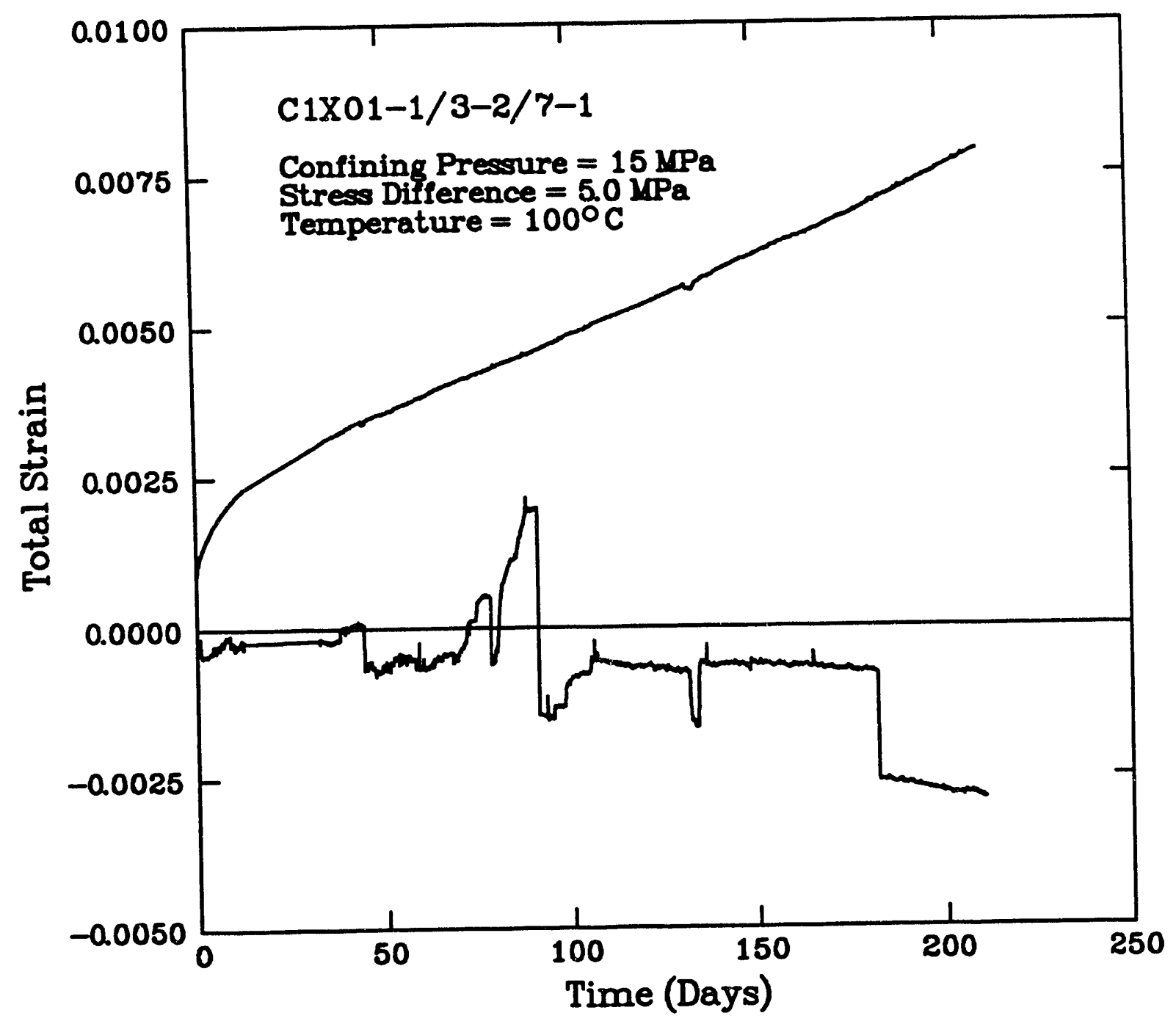

RSI-144-91-10

Figure A-6. Axial (top) and lateral (bottom) strain as a function of time for Specimen C1X01-1/3-2/7-1. 


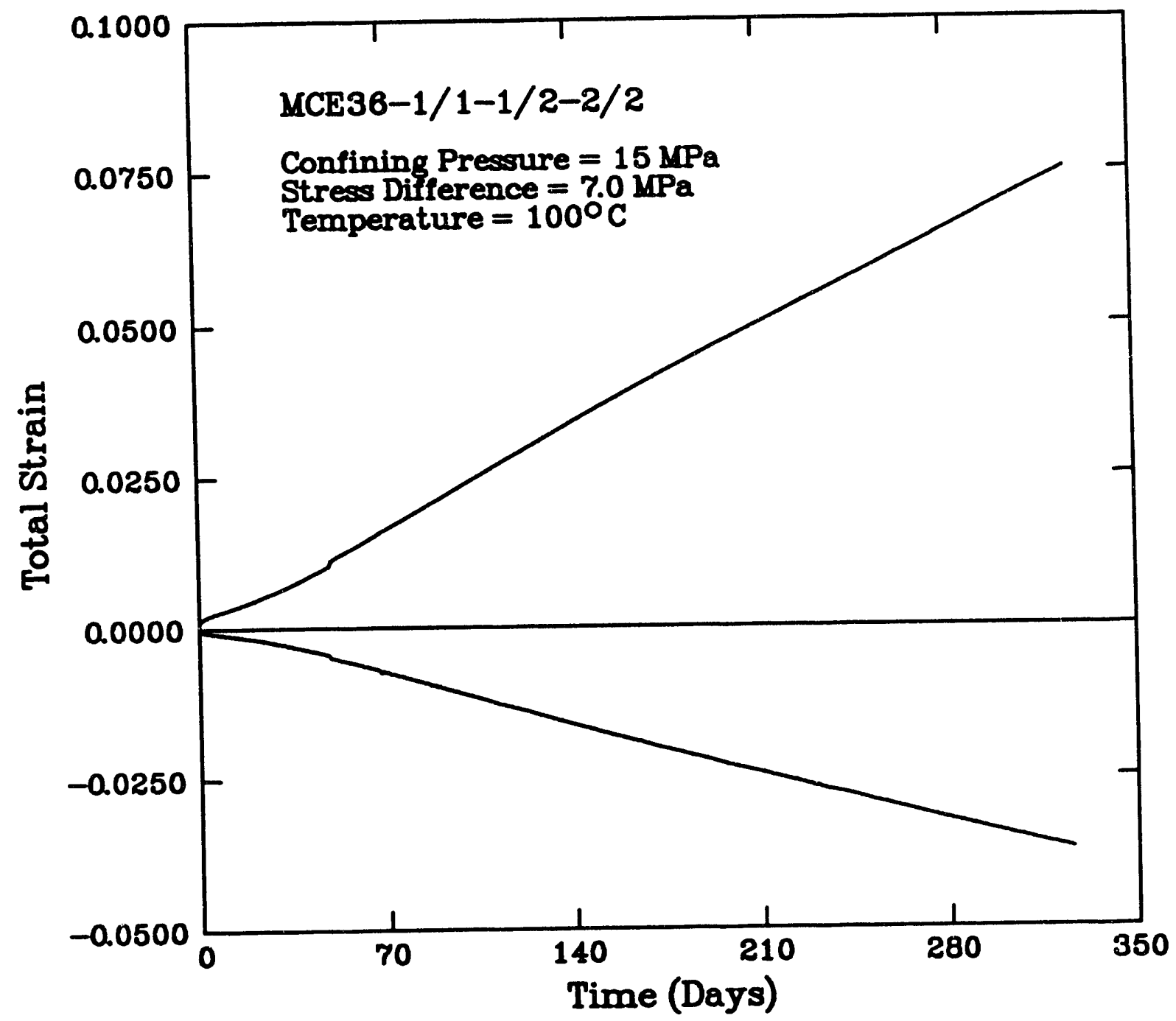

RS1-144-91-11

Figure A-7. Axial (top) and lateral (bottom) strain as a function of time for Specimen MCE36-1/1-1/2-2/2. 


\section{APPENDIX B}

\section{ARGILLACEOUS SALT}

B-1 


\section{B-2}




\section{FIGURES}

B-1. Axial (top) and lateral (bottom) strain as a function of time for Specimen L4X01-6/1-2/1-2/1. . . . . . . . . . . . . . . . . . B-5

B-2. Axial (top) and lateral (bottom) strain as a function of time for Specimen L4X01-6/1-2/1-4/1. ......................... B-6

B-3. Axial (top) and lateral (bottom) strain as a function of time for Specimen L4X01-6/1-1/1-1/1. . . . . . . . . . . . . . . . . . . . . . B-7

B-4. Axial (top) and lateral (bottom) strain as a function of time for Specimen LXX01-6/1-1/1-2/1. . . . . . . . . . . . . . . . . B-8

B-5. Axial (top) and lateral (bottom) strain as a function of time for Specimen L4X01-5/1-1/1-7/1. . . . . . . . . . . . . . . . . . B -9

B-6. Axial (top) and lateral (bottom) strain as a function of time for Specimen L4X01-6/1-1/1-3/1. . . . . . . . . . . . . . . . . B-10

B-7. Axial (top) and lateral (bottom) strain as a function of time for Specimen

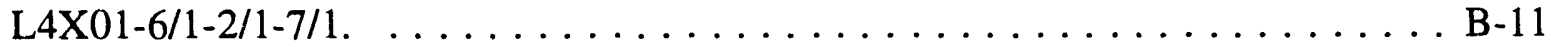

B-8. Axial (top) and lateral (bottom) strain as a function of time for Specimen L4X01-7/1-2/1-4/1. 


\section{B-4}




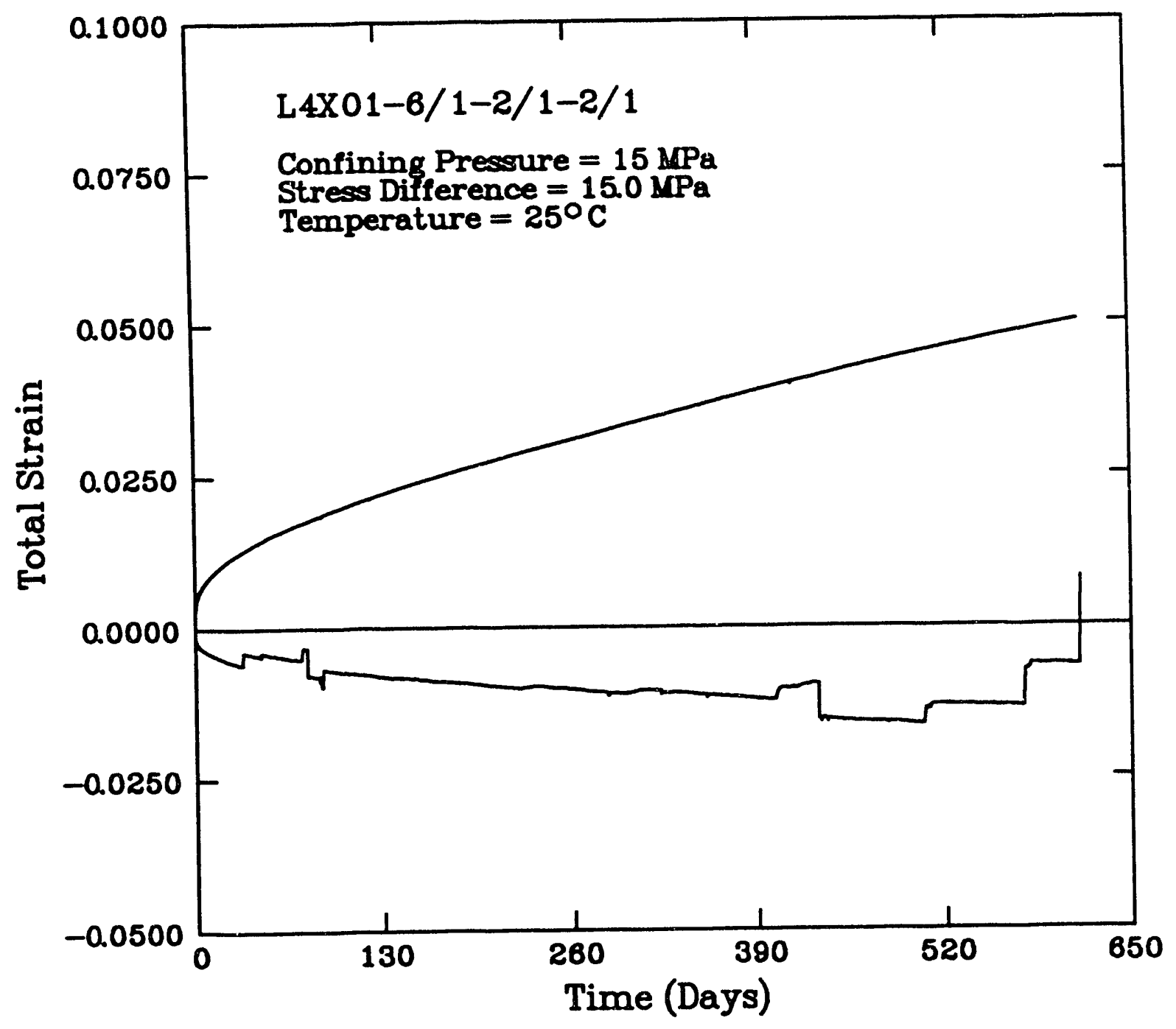

RSI-144-91-12

Figure B-1. Axial (top) and lateral (bottom) strain as a function of time for Specimen L4X01-6/1-2/1-2/1. 


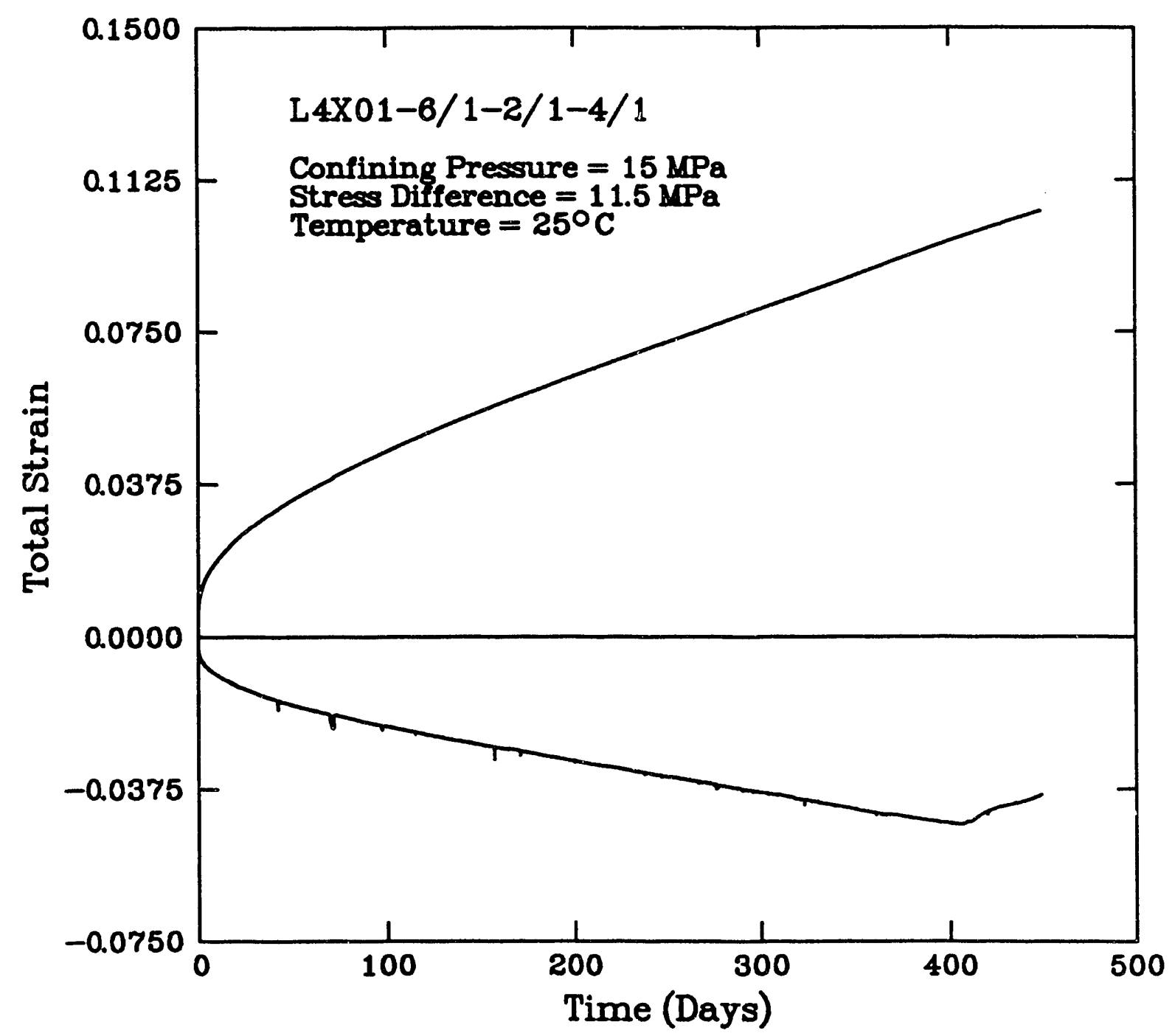

RSI-144-91-13

Figure B-2. Axial (top) and lateral (bottom) strain as a function of time for Specimen L4X01-6/1-2/1-4/1. 


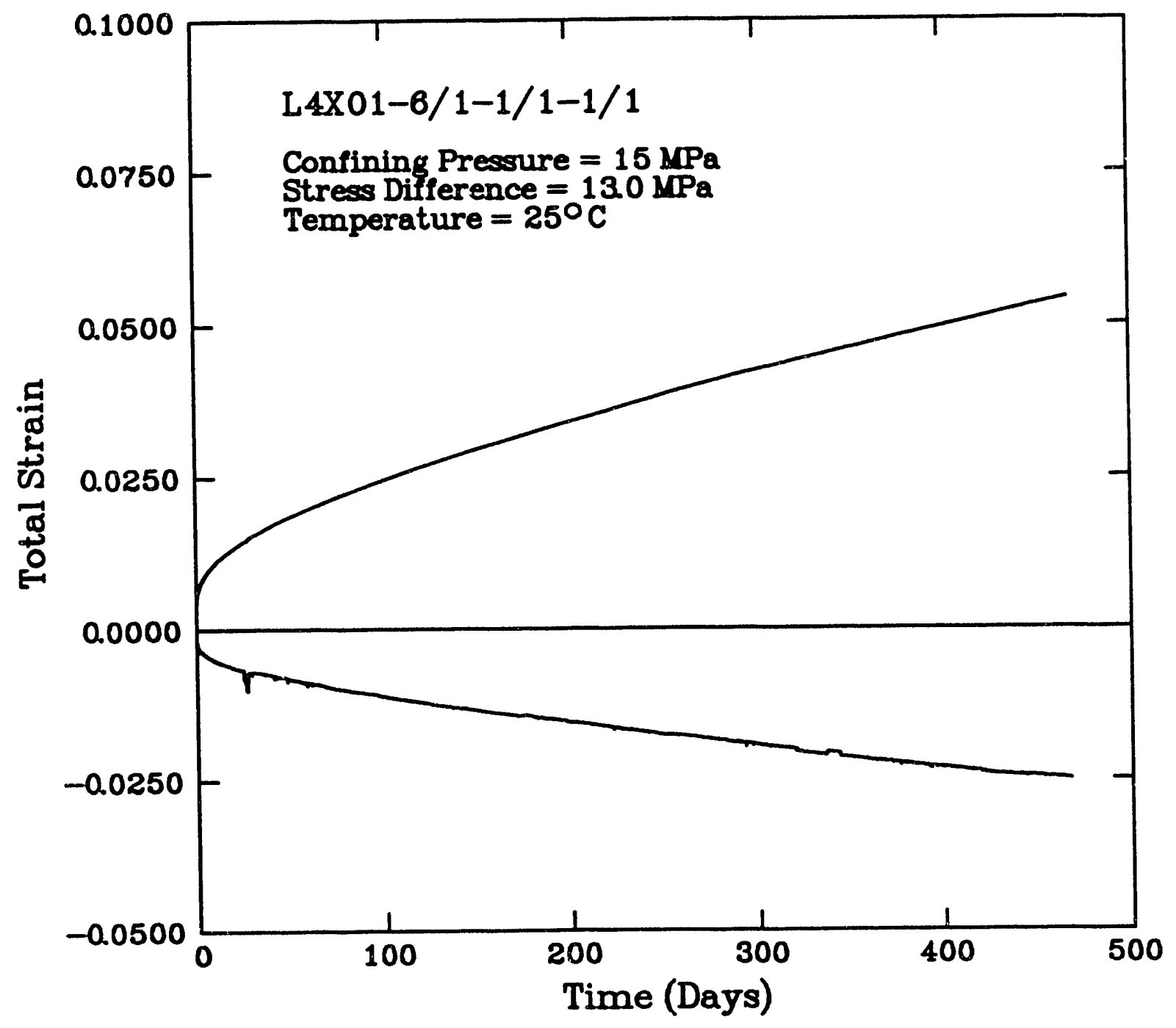

RSI-144-91.14

Figure B-3. Axial (top) and lateral (bottom) strain as a function of time for Specimen L4X01-6/1-1/1-1/1. 


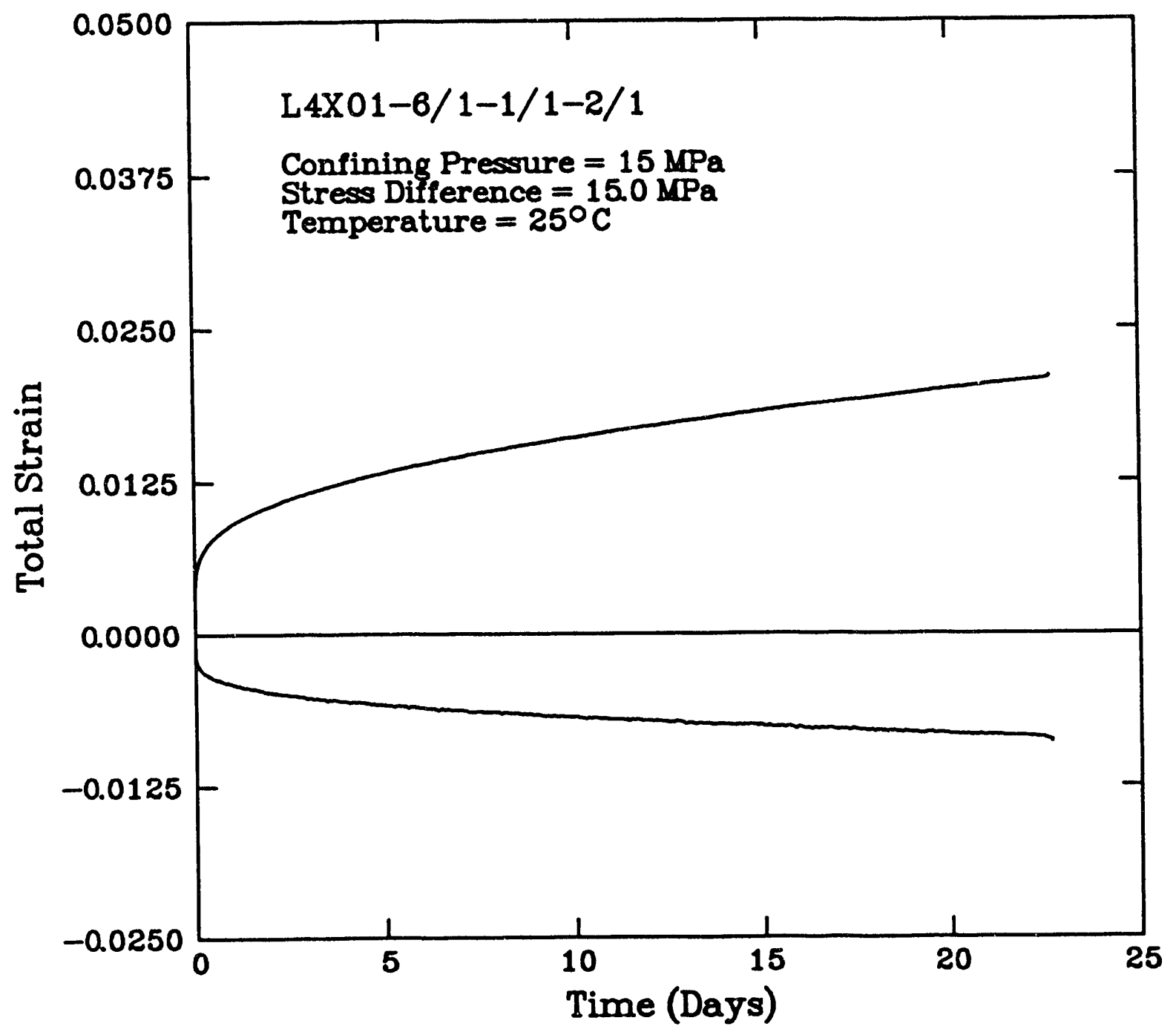

RSI.144-91.15

Figure B-4. Axial (top) and lateral (bottom) strain as a function of time for Specimen LXX01-6/1-1/1-2/1. 


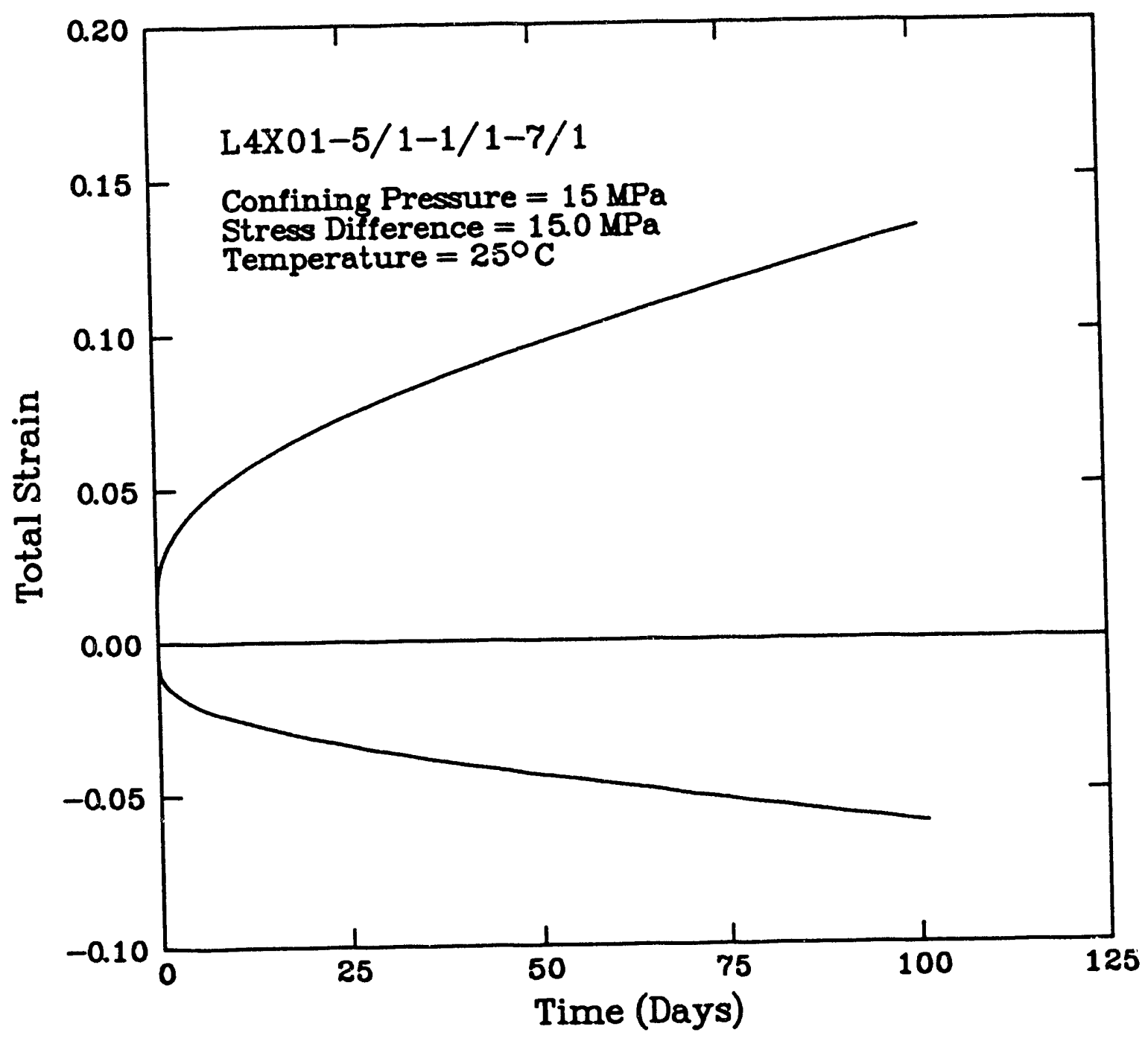

RSI-144-91-16

Figure B-5. Axial (top) and lateral (bottom) strain as a function of time for Specimen L4X01-5/1-1/1-7/1. 


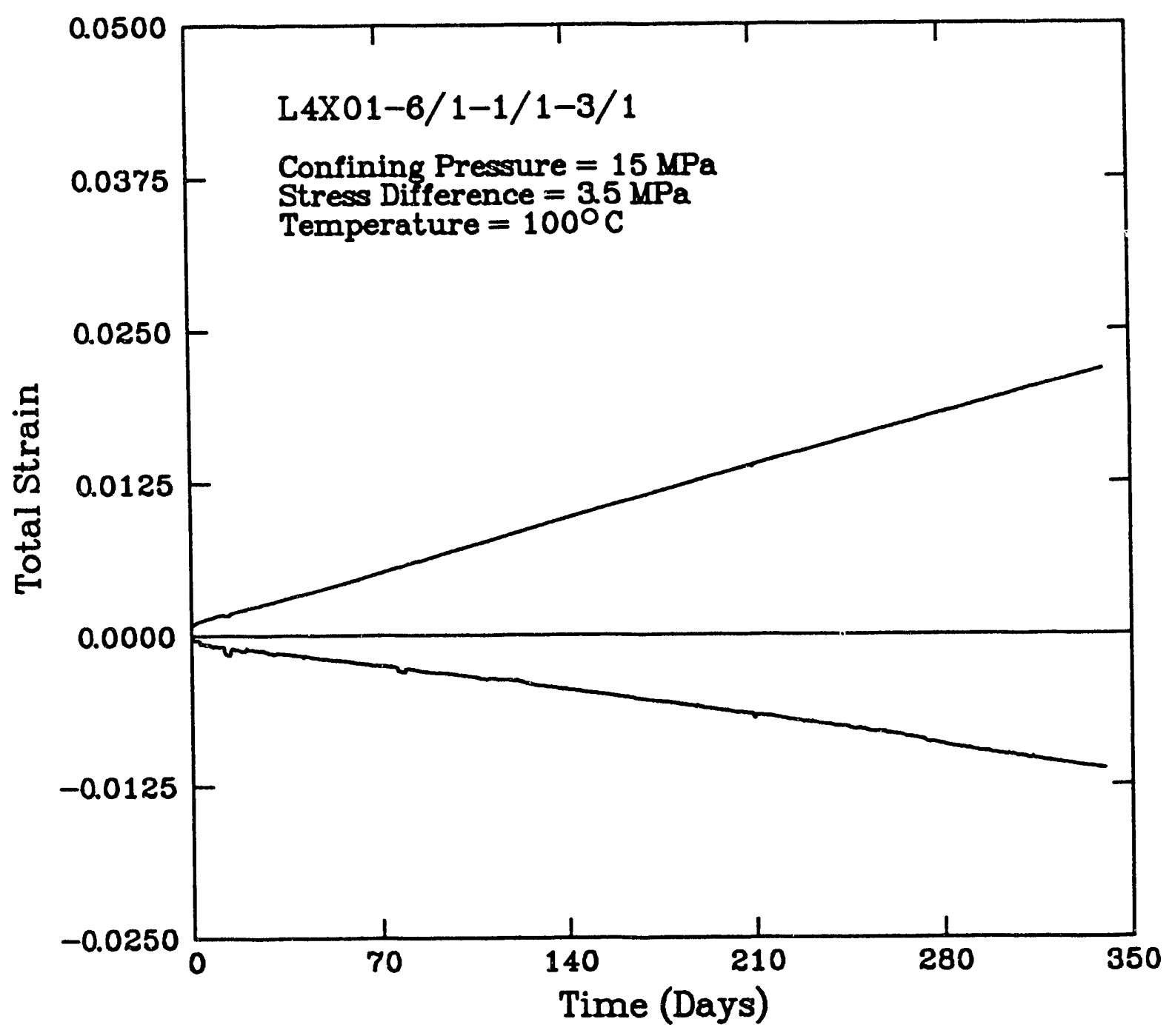

RSI-144-91-17

Figure B-6. Axial (top) and lateral (bottom) strain as a function of time for Specimen L4X01-6/1-1/1-3/1. 


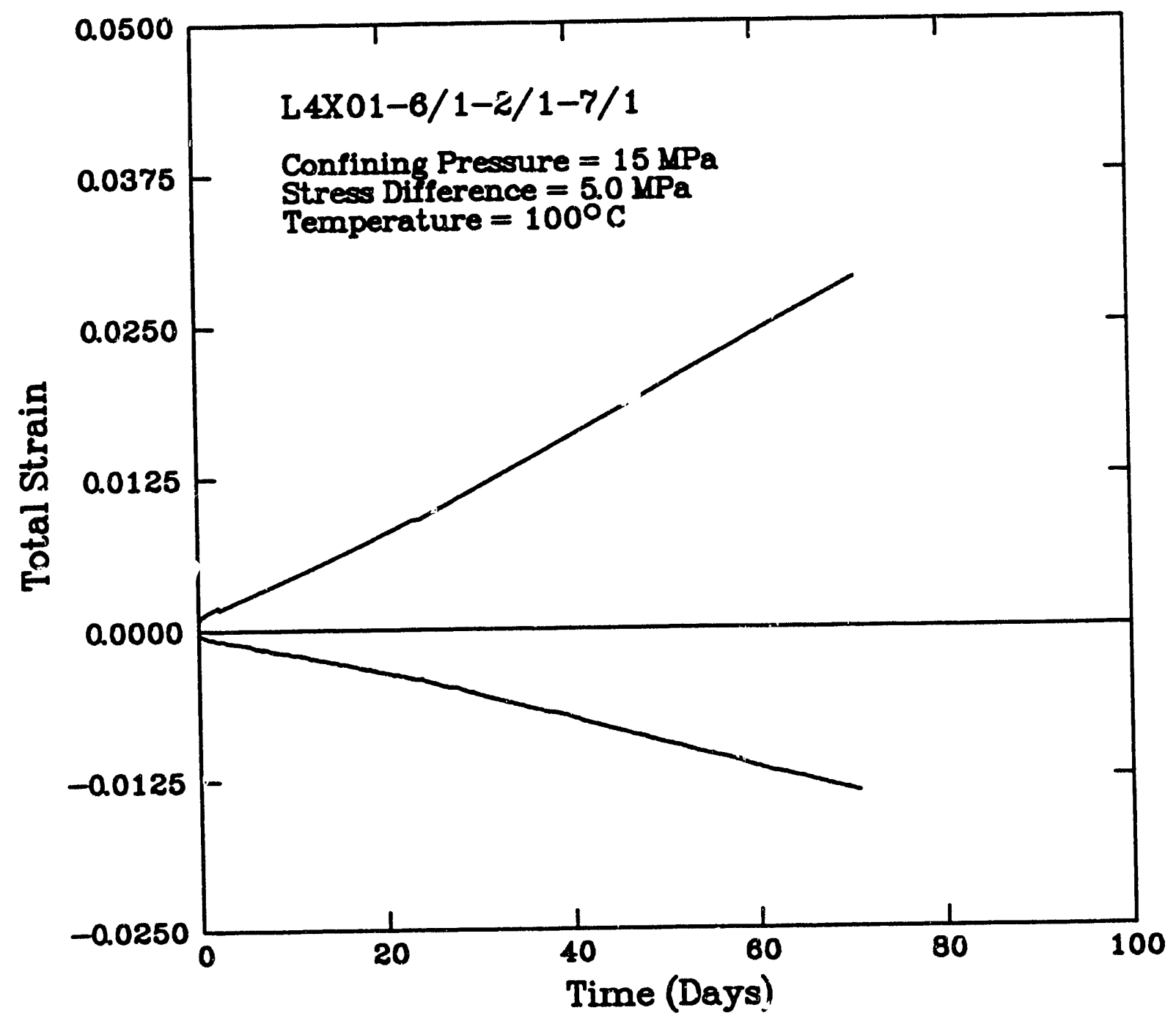

RSI-144-81-18

Figure B-7. Axial (top) and lateral (bottom) strain as a function of time for Specimen L4X01-6/1-2/1-7/1. 


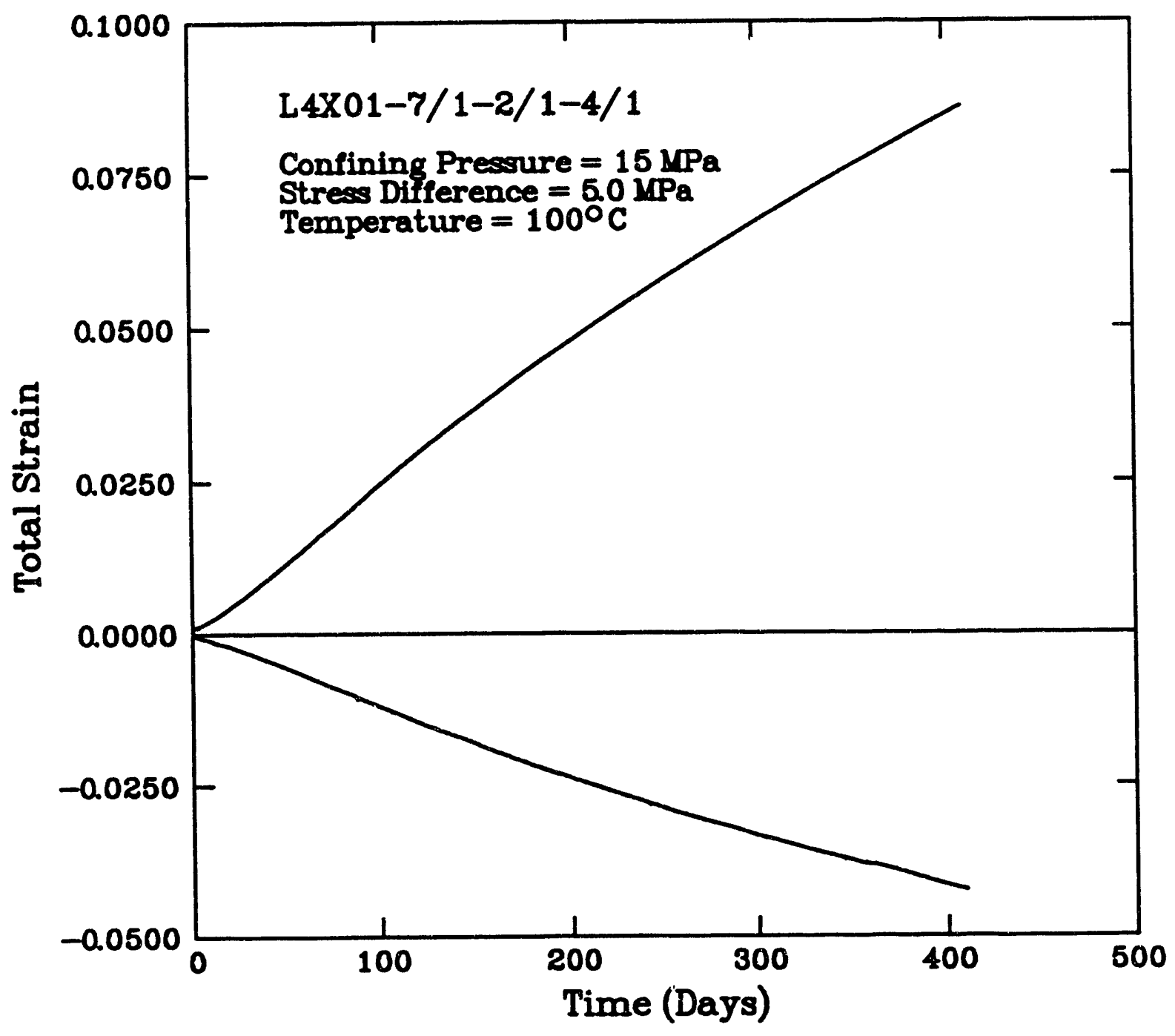

RSI-144-91-19

Figure B-8. Axial (top) and lateral (bottom) strain as a function of time for Specimen L4X01-7/1-2/1-4/1. 


\section{DISTRIBUTION}

\section{Federal Agencies:}

U.S. Department of Energy, (5)

Office of Civilian Radioactive Waste Management

Attn: Deputy Director, RW-2

Associate Director, RW-10 Office of Program Adm. and Resource Mgmt.

Associate Director, RW-20 Office of Facility Siting and Development

Associate Director, RW-30

Office of Systems Integ. and Regulations

Associate Director, RW-40

Office of External

Relations and Policy

Forrestal Building

1000 Independence Avenue, SW

Washington, DC 20585

U.S. Department of Energy (4)

WIPP Project Integration Office

Attn: W.J. Arthur III

L.W. Gage

P.J. Higgens

D.A. Olona

P.O. Box 5400

Albuquerque, NM 87115-5400

U.S. Department of Energy

Albuquerque Operations Office

Attn: National Atomic Museum Library

P.O. Box 5400

Albuquerque, NM $87185-5400$

U.S. Department of Energy (4)

WIPP Project Office (Carlsbad)

Attn: R. Becker

V. Daub

J. Lippis

J.A. Mcwhinney

P.O. Box 3090

Carlsbad, NM 88221
U.S. Department of Energy

Research \& Waste Management Div.

Attn: Director

P.O. Box E

Oak Ridge, TN 37831

U.S. Department of Energy

Attn: E. Young

Room E-178

GAO/RCED/GTN

Washington, DC 20545

U.S. Department of Energy

Office of Environmental Restoration and Waste Management

Attn: J. Lytle EM30 (Trevion II) M. Frei EM34 (Trevion II) (3)

S. Schneider EM-342 (Trivion II)

Washington, DC 20585-0002

U.S. Department of Energy (2)

Office of Environment, Safety and Health

Attn: C. Borgstrom, EH-25

R. Pelletier, EH-231

Washington, DC 20585

U.S. Department of Energy (2)

Idaho Operations Office

Fuel Processing and Waste Management

Division

785 DOE Place

Idaho Falls, ID 83402

U.S. Environmental Protection Agency (2) Attn: M. Oge

Office of Radiation Programs (ANR-460)

Washington, DC 20460 
U.S. Geological Survey (2)

Water Resources Division

Attn: R. Livinston

Suite 200

4501 Indian School Road, NE

Albuquerque, NM 87110

U.S. Nuclear Regulatory Commission

Attn: H. Marson

Mail Stop 623SS

Washington, DC 20555

Boards:

Defense Nuclear Facilities Safety Board

Attn: D. Winters

Suite 700

625 Indiana Avenue NW

Washington, DC 20004

Nuclear Waste Technical

Review Board (2)

Attn: Chairman

Suite 910

$$
\text { S.J.S. Parry }
$$

1100 Wilson Blvd.

Arlington, VA 22209-2297

Advisory Committee on Nuclear Waste Nuclear Regulatory Commission

Attn: R. Major

7920 Norfolk Avenue

Bethesda, MD 20814

State Agencies:

Environmental Evaluation Group (3)

Attn: Library

Suite F-2

7007 Wyoming Blvd., NE

Albuquerque, NM 87109

New Mexico Bureau of Mines \&

Mineral Resources

Socorro, NM 87801
New Mexico Department of Energy, Minerals, \& Natural Resources Dept.

Attn: Librarian

2040 S. Pacheco

Santa Fe, NM 87505

New Mexico Environmental Dept. (3)

Secretary of the Environment

Attn: J. Espinosa

1190 St. Francis Drive

Santa Fe, NM 87503-0968

New Mexico Environment Dept.

WIPP Project Site

Attn: P. McCasland

P.O. Box 3090

Carlsbad, NM 88221

\section{Laboratories/Corporations}

Battelle Pacific Northwest

Laboratories

Attn: R.E. Westerman, MSIN P8-44

Battelle Boulevard

Richland, WA 99352

INTERA Inc.

Attn: J.F. Pickens

Suite \#300

6850 Austin Center Blvd.

Austin, TX 78731

INTERA Inc.

Attn: W. Stensrud

P.O. Box 2123

Carlsbad, NM 88221

IT Corporation

Attn: R.F. McKinney

Regional Office - Suite 700

5301 Central Ave., NE

Albuquerque, NM 87108

Los Alamos National Laboratory

Attn: B. Erdal, CNC-11

P.O. Box 1663

Los Alamos, NM 87545 
RE/SPEC Inc.

Attn: W.E. Coons

4775 Indian School Rd., N.E.

Suite 300

Albuquerque, NM 87110

RE/SPEC Inc. (10)

Attn: G.D. Callahan

A.F. Fossum

T.W. Pfeifle

J.L. Ratigan

P.O. Box 725

Rapid City, SD 57709

Southwest Research Institute

Center for Nuclear Waste

Regulatory Analysis (4)

Attn: P.K. Nair

6220 Culebra Road

San Antonio, TX 78228-0510

SAIC

Attn: D.C. Royer

101 Convention Center Dr.

Las Vegas, NV 89109

SAIC

Attn: H.R. Pratt

10260 Campus Point Drive

San Diego, CA 92121

SAIC (2)

Attn: M. Davis

J. Tollison

2109 Air Park Rd., SE

Albuquerque, NM 87106

Tech Reps Inc. (3)

Attn: J. Chapman

R. Jones

C. Northrop-Salazar

T. Peterson

5000 Marble, NE

Albuquerque, NM 87110
TRW Environmental Safety Systems

Attn: L. Wildman

2650 Park Tower Dr.

Suite 1300

Vienna, VA 22180-7306

Westinghouse Electric Corp. (4)

Attn: Library

C. Cox

L. Fitch

R. Kehrman

P.O. Box 2078

Carlsbad, NM 88221

Universities:

University of New Mexico

Geology Department

Attn: Library

Albuquerque, NM 87131

University of Washington

Attn: G.R. Heath

College of Ocean and Fishery Sciences

583 Henderson Hall

Seattle, WA 98195

Individuals:

P. Drez

8816 Cherry Hills Rd., NE

Albuquerque, NM 87111

Dennis W.Powers

Star Route Box 87

Anthony, TX 79821

Libraries:

Thomas Brannigan Library

Attn: D.Dresp

106 W. Hadley Street

Las Cruces, NM 88001 
Government Publications Department

Zimmerman Library

University of New Mexico

Albuquerque, NM 87131

Hobbs Public Library

Attn: M. Lewis

509 N. Ship Street

Hobbs, NM 88248

New Mexico Junior College

Pannell Library

Attn: R. Hill

Lovington Highway

Hobbs, NM 88240

New Mexico State Library

Attn: N. McCallan

325 Don Gasper

Santa Fe, NM 87503

New Mexico Tech

Martin Speere Memorial Library

Campus Street

Socorro, NM 87810

WIPP Public Reading Room

Attn: Director

Carlsbad Public Library

101 S. Halagueno Street

Carlsbad, NM 88220

\section{National Academy of Sciences,} WIPP Panel:

Dr. Charles Fairhurst, Chairman

Department of Civil and

Mineral Engineering

University of Minnesota

500 Pillsbury Dr., SE

Minneapolis, MN 55455

Howard Adler

Oak Ridge Associated Universities

Medical Sciences Division

P.O. Box 117

Oak Ridge, TN 37831-0117
Ina Alterman

Board on Radioactive Waste Management

GF456

2101 Constitution Ave.

Washington, CD 20418

John D. Bredehoeft

Western Region Hydorlogist

Water Resources Division

U.S. Geological Survey (M/S 439)

345 Middlefield Road

Menlo Park, CA 94025

Fred Ernsberger

250 Old Mill Road

Pittsburgh, PA 15238

Dr. Rodney C. Ewing

Department of Geology

University of New Mexico

200 Yale, NE

Albuquerque, NM 87131

B. John Garrick

Pickard, Lowe \& Garrick, Inc.

2260 University Drive

Newport Beach, CA 92660

Leonard F. Knoikow

U.S. Geological Survey

431 National Center

Reston, VA 22092

Peter B. Myers

National Academy of Sciences

Board on Radioactive Waste Management

2101 Constitution Ave.

Washington, DC 20418

Jeremiah O'Driscoll

505 Valley Hill Drive

Atlanta, GA 30350

Dr. Christopher G. Whipple

Clement Interntional

Suite 1380

160 Spear St.

San Francisco, CA 94105 


\section{Foreign Addresses:}

Studiecentrum Voor Kernenergie

Centre D'Energie Nucleaire

Attn: Mr. A. Bonne

SCK/CEN

Boeretang 200

B-2400 Mol

BELGIUM

Atomic Energy of Canada, Ltd. (3) Whiteshell Research Establishment

Attn: P. Goodwin

M. Stevens

D. Wushke

Pinewa, Manitoba

CANADA ROE 1LO

Mr. Francois Chenevier, Director (2)

ANDRA

Route du Panorama Robert Schumann

B.P.38

92266 Fontenay-aux-Roses Cedex

FRANCE

OECD Nuclear Energy Agency

Attn: Mr. Jean-Pierre Olivier

Division of Radiation Protection and

Waste Management

38 Boulevard Suchet

75016 Paris

FRANCE

Claude Sombret

Centre D'Etudes Nucleaires

De La Vallee Rhone

CEN/VALRHO

S.D.H.A. BP 171

30205 Bagnols-Sur-Ceze

FRANCE

Bundesministerium fur Forschung und

Technologie

Postfach 200706

5300 Bonn 2

FEDERAL REPUBLIC OF GERMANY
Gesellschaft fur Reaktorsicherheit (GES) (2)

Attn: B. Baltes

W. Muller

Schwertnergasse 1

D-5000 Colone

GERMANY

Bundesanstalt fur Geowissenschaften und Rohstoffe (3)

Attn: Michael Langer

Postfach 510153

3000 Hannover 51

GERMANY

Institut fur Tieflagerung (4)

Attn: K. Kuhn

Theodor-Heuss-Strasse 4

D-3300 Braunschweig

GERMANY

Physikalisch-Technische

Bundesanstalt

Attn: Peter Brenneke

Postfach 3345

D-3300 Braunschweig

GERMANY

Japan Atomic Energy Research Institute

Attn: Shingo Tashiro

Tokai-Mura, Ibaraki-Ken

319-11 JAPAN

Netherlands Energy Research

Foundation ECN (2)

Attn: L.H. Vons

3 Westerduinweg

P.O. Box 1

1755 ZG Petten

THE NETHERLANDS

Svensk Karnbransleforsorjning AB

Attn: Fred Karlsson

Project KBS

Karnbranslesakerhet

Box 5864

10248 Stockholm

SWEDEN 
Nationale Genossenschaft fur die

Lagerung Radioaktiver Abfalle (2)

Attn: S. Volvoris

P. Zuidema

Hardstrasse 73

CH-5430 Wettingen

SWITZERLAND

D.R. Knowles

British Nuclear Fuels, plc

Risley, Warrington, Cheshire WA3 6AS 1002607

UNITED KINGDOM

AEA Technology

Attn: J.H. Rees

D5W Culham Laboratory

Abington, Oxfordshire OX14 3DB

UNITED KINGDOM

AEA Technology

Attn: W.R. Rodwell

044/A31 Winfrith Technical Centre

Dorchester, Dorset DT2 8DH

UNITED KINGDOM

AEA Technology

Attn: J.E. Tinson

B4244 Harwell Laboratory

Didcot, Oxfordshire OX11 ORA

UNITED KINGDOM

\section{Sandia Internal:}

$\begin{array}{ll}1502 & \text { J.C. Cummings } \\ 1561 & \text { H.S. Morgan } \\ 6000 & \text { D.L. Hartley } \\ 6100 & \text { R.W. Lynch } \\ 6117 & \text { W.R. Wawersik } \\ 6119 & \text { E.D. Gorham } \\ 6121 & \text { J.R. Tillerson } \\ 6121 & \text { Staff (7) } \\ 6121 & \text { D.E. Munson (10) } \\ 6300 & \text { D.E. Ellis } \\ 6302 & \text { L.E. Shephard } \\ 6303 & \text { W.D. Weart } \\ 6303 & \text { S.Y. Pickering } \\ 6305 & \text { S.A. Goldstein } \\ 6341 & \text { A.L. Stevens } \\ 6342 & \text { D.R. Anderson } \\ 6342 & \text { Staff (20) } \\ 6343 & \text { S.A. Orrell } \\ 6343 & \text { Staff (2) } \\ 6345 & \text { R.C. Lincoln } \\ 6345 & \text { Staff (9) } \\ 6347 & \text { D.R. Schafer } \\ 6351 & \text { R.E. Thompson } \\ 6352 & \text { D.P. Garber } \\ 6352 & \text { S.E. Sharpton } \\ 6352 & \text { WIPP Central Files (10) } \\ 7141 & \text { Technical Library (5) } \\ 7151 & \text { Technical Publications } \\ 7613-2 & \text { Document Processing for } \\ 8523-2 & \text { DOE/OSTI (10) } \\ & \text { Central Technical Files }\end{array}$



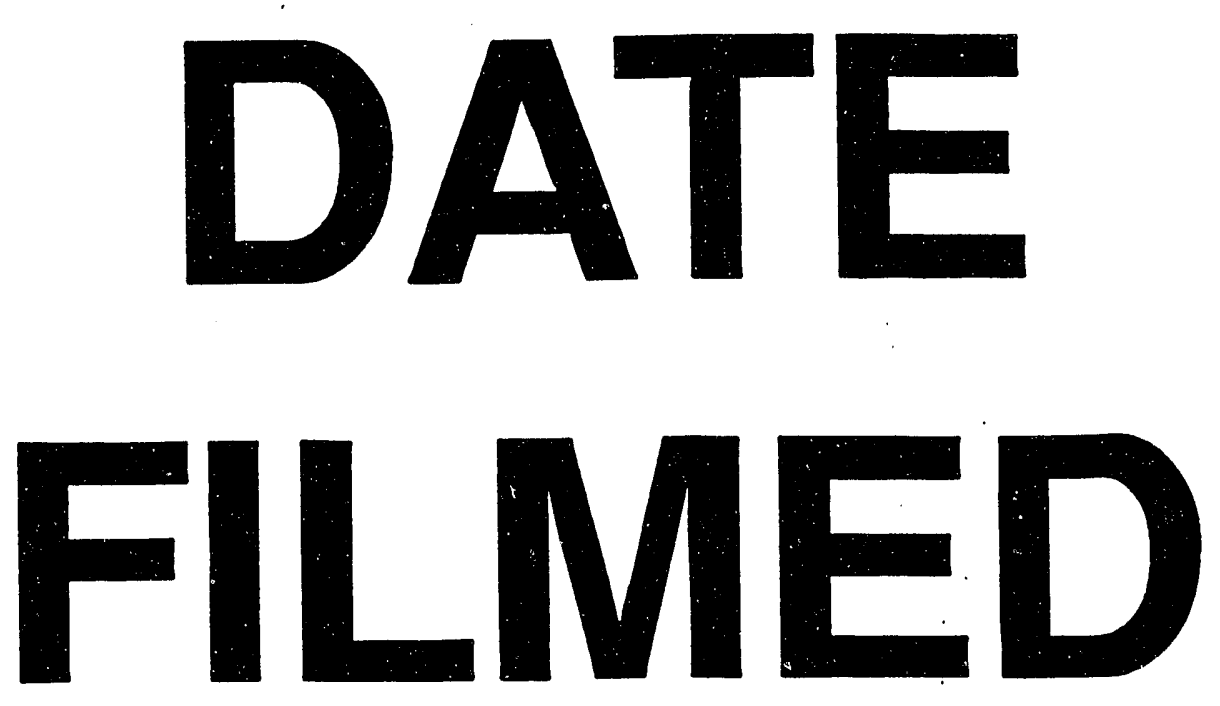

$9 / 28 / 93$
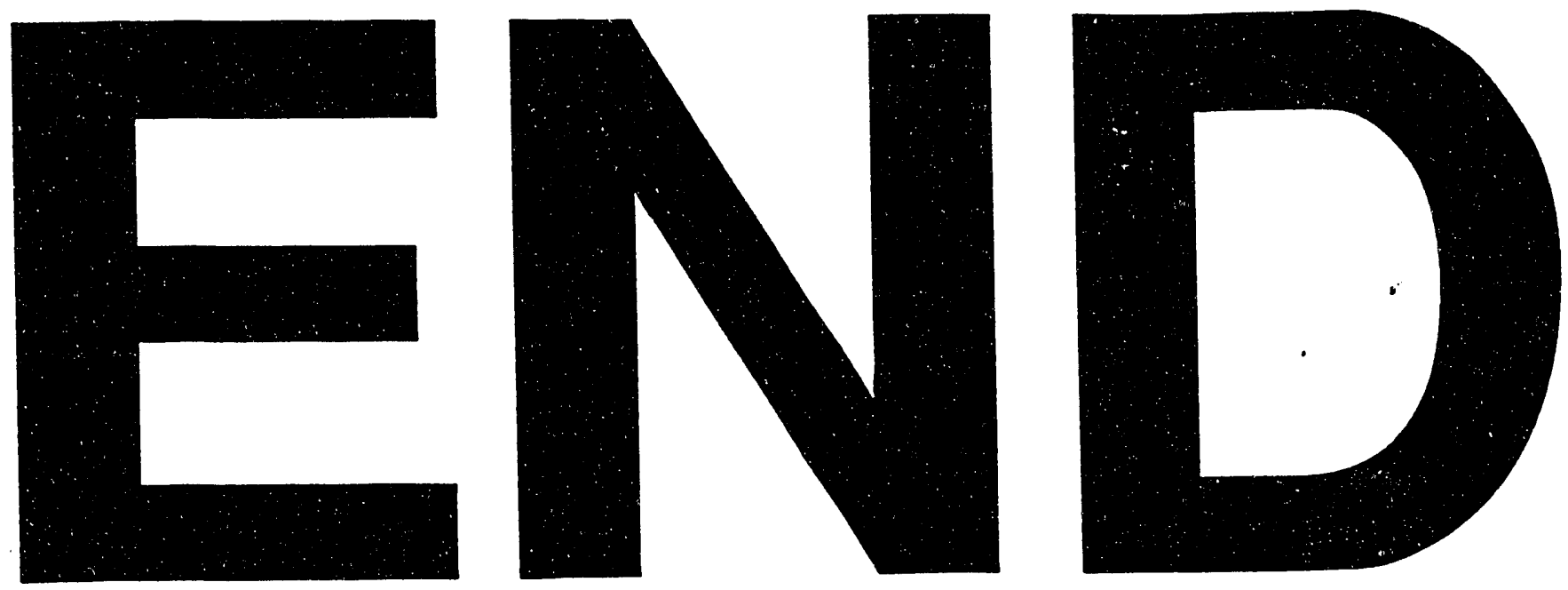
